\title{
P2X receptor-mediated ATP purinergic signaling in health and disease
}

\author{
This article was published in the following Dove Press journal: \\ Cell Health and Cytoskeleton \\ 18 September 2012 \\ Number of times this article has been viewed
}

\section{Lin-Hua Jiang}

School of Biomedical Sciences, Faculty of Biological Sciences, University of Leeds, Leeds, United Kingdom
Correspondence: Lin-Hua Jiang School of Biomedical Sciences, Faculty of Biological Sciences, University of Leeds, Leeds LS2 9JT, United Kingdom

Tel +44 0 I I 3 343423 I

Email I.h.jiang@leeds.ac.uk
Abstract: Purinergic P2X receptors are plasma membrane proteins present in a wide range of mammalian cells where they act as a cellular sensor, enabling cells to detect and respond to extracellular adenosine triphosphate (ATP), an important signaling molecule. P2X receptors function as ligand-gated $\mathrm{Ca}^{2+}$-permeable cationic channels that open upon ATP binding to elevate intracellular $\mathrm{Ca}^{2+}$ concentrations and cause membrane depolarization. In response to sustained activation, $\mathrm{P} 2 \mathrm{X}$ receptors induce formation of a pore permeable to large molecules. $\mathrm{P} 2 \mathrm{X}$ receptors also interact with distinct functional proteins and membrane lipids to form specialized signaling complexes. Studies have provided compelling evidence to show that such P2X receptor-mediated ATP-signaling mechanisms determine and regulate a growing number and diversity of important physiological processes, including neurotransmission, muscle contraction, and cytokine release. There is accumulating evidence to support strong causative relationships of altered receptor expression and function with chronic pain, inflammatory diseases, cancers, and other pathologies or diseases. Numerous high throughput screening drug discovery programs and preclinical studies have thus far demonstrated the proof of concepts that the P2X receptors are druggable targets and selective receptor antagonism is a promising therapeutics approach. This review will discuss the recent progress in understanding the mammalian P2X receptors with respect to the ATP-signaling mechanisms, physiological and pathophysiological roles, and development and preclinical studies of receptor antagonists.

Keywords: extracellular ATP, ion channel, large pore, signaling complex, chronic pain, inflammatory diseases

\section{Introduction to the $\mathbf{P} \mathbf{X}$ receptors}

It has become well established that adenosine triphosphate (ATP) released from healthy cells as well as from damaged or dying cells acts as an important extracellular signaling molecule. ${ }^{1-5}$ The fast actions of extracellular ATP are largely mediated by the purinergic $\mathrm{P} 2 \mathrm{X}$ receptors that are ligand-gated ion channels on the cell surface.

There are seven different mammalian genes encoding a family of P2X proteins or receptor subunits, namely, P2X1-P2X7, with the human P2X subunits being 377 (hP2X6) to 595 amino acid residues (hP2X7) in length. ${ }^{6}$ They all have two transmembrane domains (TM1 and TM2) and a large extracellular cysteine-rich domain with short $\mathrm{N}$-terminus and $\mathrm{C}$-terminus of considerably variable length residing intracellularly. A various number of alternative splicing variants have been identified..$^{6-12}$ Studies of heterologously expressed P2X receptors suggest that all P2X subunits except the P2X6 can form homomeric receptors ${ }^{6,13,14}$ and that two different subunits can assemble heteromeric receptors with $\mathrm{P} 2 \mathrm{X} 1 / 2, \mathrm{P} 2 \mathrm{X} 1 / 4, \mathrm{P} 2 \mathrm{X} 1 / 5, \mathrm{P} 2 \mathrm{X} 2 / 3, \mathrm{P} 2 \mathrm{X} 2 / 5$, 
$\mathrm{P} 2 \mathrm{X} 2 / 6$, and $\mathrm{P} 2 \mathrm{X} 4 / 6$ being reported so far. ${ }^{6,15}$ Such studies have also gathered considerable evidence to consistently support that the $\mathrm{P} 2 \mathrm{X}$ receptor is a trimer and ATP binds to a novel site located at the subunit interface. ${ }^{13,16-20}$ Such receptor stoichiometry and inter-subunit ATP-binding sites have been confirmed in the recently published crystal structures of the zebrafish P2X4 receptors with the intracellular N- and C-termini being truncated, ${ }^{21,22}$ an exciting breakthrough in $\mathrm{P} 2 \mathrm{X}$ receptor research in recent years.

The significant sequence homology to the zebrafish P2X4 receptor has allowed for the first time to generate by computational modeling the structures of the mammalian P2X receptors. ${ }^{23-26}$ Figure 1 shows a structural model of the human P2X7 receptor. In an analogy, it adopts a chalice-like architecture, and each subunit bears a dolphin-like shape with the large extracellular domain and the TM helices akin to the body and the fluke, respectively. The $\mathrm{P} 2 \mathrm{X}$ receptor ion channels are permeable to $\mathrm{Ca}^{2+}, \mathrm{Na}^{+}$, and $\mathrm{K}^{+}$. As has been recently reviewed, ${ }^{23,24}$ such structural information has greatly helped to build up a more insightful view on the ATP-binding site, ion-conducting pathway, and other structure-function relationships of the mammalian $\mathrm{P} 2 \mathrm{X}$ receptors based on the results from the functional studies of mutant receptors over the past decade.

The P2X receptors, as a family of ligand-gated ion channels, in terms of their subunit membrane topology and receptor stoichiometry, differ from the other two classical ligand-gated ion channels, ie, the cysteine-loop receptors such as the nicotinic acetylcholine (nACh) and $\gamma$-aminobutyric acid (GABA) receptor ion channels, which are pentamers with four transmembrane domains in each subunit, and the glutamate receptor ion channels, which are tetramers with three transmembrane and one re-entrant loop domains in each subunit. ${ }^{5}$ It was striking however to discover by structural determination that the $\mathrm{P} 2 \mathrm{X}$ receptor ion channels and the acid-sensing ion channels, despite no sequence relatedness, have a virtually identical ion-conducting pathway as well as the same subunit membrane topology and receptor stoichiometry. ${ }^{27}$

This review article will discuss the recent progress in understanding the mammalian P2X receptors on the ATP signaling mechanisms, physiological and pathophysiological roles, and development and preclinical studies of receptor antagonists.

\section{P2X receptor-mediated ATP signaling mechanisms}

$\mathrm{P} 2 \mathrm{X}$ receptor expression at the mRNA, protein, and/or functional levels has been documented in a vast variety of cells, including neurons and glial cells in the central (CNS) and peripheral (PNS) nervous systems, muscle cells, epithelial cells, endothelial cells, endocrine cells, bone cells, and immune cells, and such widespread distribution suggests a role for the $\mathrm{P} 2 \mathrm{X}$ receptors in ATP signaling in a diversity of physiological processes. ${ }^{1,3,6}$ The $\mathrm{P} 2 \mathrm{X}$ receptors mediate ATP signaling mainly through three mechanisms: they function
A

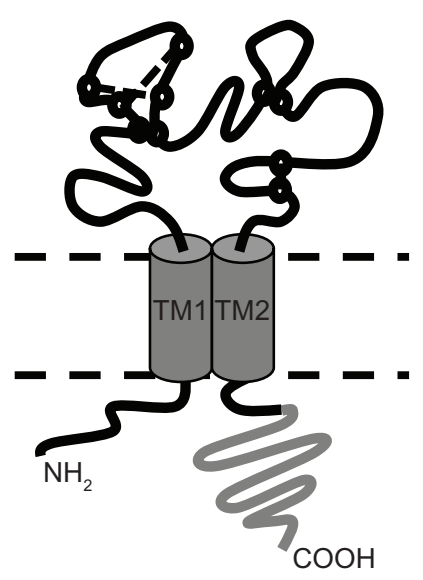

B

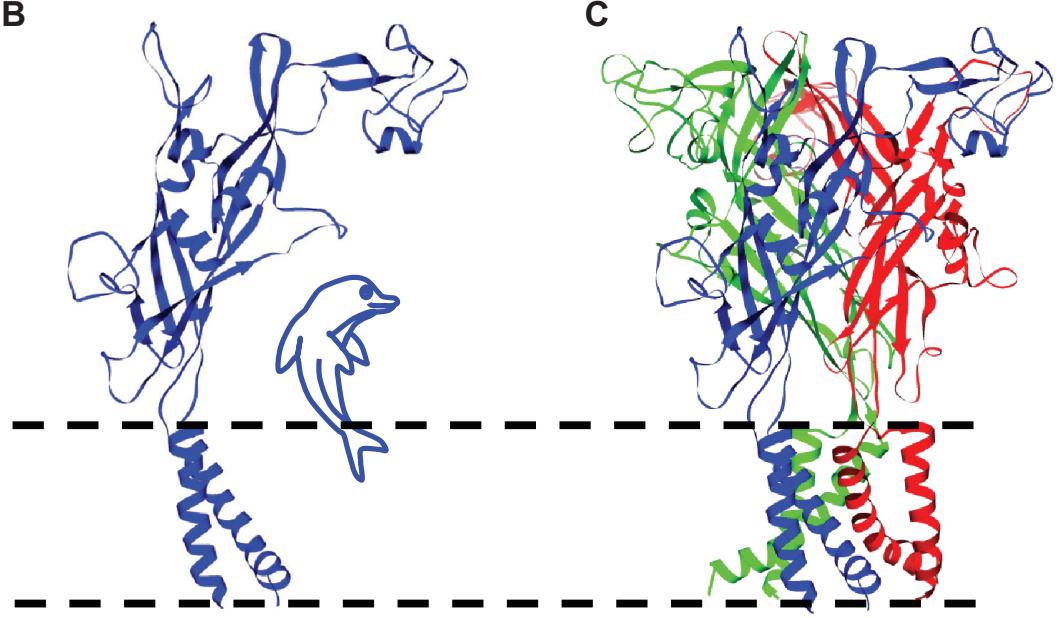

Figure I Structural features of P2X receptors. (A) A cartoon presentation showing that a mammalian P2X receptor subunit consists of two transmembrane domains (TMI and TM2) linked by a large extracellular domain and intracellular $\mathrm{N}$ - and $\mathrm{C}$-termini. There are 10 conserved cysteine residues denoted by open circles that form five pairs of intra-subunit disulfide bonds denoted by dotted lines. The P2X7 receptor subunit has an exceptionally long $\mathrm{C}$-terminus compared with other $\mathrm{P} 2 \mathrm{X}$ receptor subunits. (B and C) The human P2X7 receptor subunit (B) and receptor (C) generated by computational modeling using the crystal structure of the zebrafish P2X4 receptor in the closed state.

Notes: The architecture of the single subunit and the trimeric receptor is an analogy to the rising dolphin and the chalice, respectively. The three subunits are represented in different colors. 
as ligand-gated $\mathrm{Ca}^{2+}$-permeable cationic channels, induce formation of a large pore, and form signaling complexes with interacting proteins and membrane lipids. For simplicity, these mechanisms are discussed separately next, but the reader should bear in mind that such mechanisms are not mutually exclusive and, as a matter of fact, commonly operate in an interrelated manner.

\section{Ligand-gated $\mathrm{Ca}^{2+}$-permeable cationic channels}

All mammalian $\mathrm{P} 2 \mathrm{X}$ receptor ion channels are $\mathrm{Ca}^{2+}$-permeable. As a whole, the $\mathrm{P} 2 \mathrm{X}$ receptor ion channels mediate more $\mathrm{Ca}^{2+}$ influx than the glutamate receptor ion channels and the nACh receptor ion channels. ${ }^{28}$ Conceivably, activation of the $\mathrm{P} 2 \mathrm{X}$ receptors opens an important route for extracellular $\mathrm{Ca}^{2+}$ influx to elevate cytosolic $\mathrm{Ca}^{2+}$ concentration $\left(\left[\mathrm{Ca}^{2+}\right]_{\mathrm{c}}\right)$. The P2X receptor ion channels equally well permeate $\mathrm{Na}^{+}$ and $\mathrm{K}^{+} . \mathrm{Na}^{+}$influx and/or $\mathrm{K}^{+}$efflux can depolarize the plasma membrane potential, which in turn activates the voltage-gated $\mathrm{Ca}^{2+}$ channels $\left(\mathrm{Ca}_{\mathrm{v}}\right)$ to enhance the $\mathrm{Ca}^{2+}$ influx. By contrast, $\mathrm{P} 2 \mathrm{X}$ receptor-mediated membrane depolarization can reduce $\mathrm{Ca}^{2+}$ influx through the store-operated $\mathrm{Ca}^{2+}$ (SOC) channels that open following activation of ATP-sensitive G-proteincoupled $\mathrm{P} 2 \mathrm{Y}$ receptors and subsequent depletion of the intracellular $\mathrm{Ca}^{2+}$ store. ${ }^{29}$

The above $\mathrm{P} 2 \mathrm{X}$ receptor-mediated mechanisms and particularly the increases in the $\left[\mathrm{Ca}^{2+}\right]_{\mathrm{c}}$ represent the key and widespread ATP signaling mechanism in a diversity of physiological processes; for example, release of neurotransmitters such as glutamate, GABA, and ATP, and synaptic plasticity and neuron-glia communications, ${ }^{30-34}$ smooth-muscle contraction, ${ }^{35-37}$ flow-induced $\mathrm{Ca}^{2+}$ signaling in endothelial cells and flow-dependent control of vascular tone and remodeling, ${ }^{38}$ cell proliferation, ${ }^{7,39}$ and generation of vascular endothelial growth factors from monocytes ${ }^{40}$ and ATP release from satellite glial cells. ${ }^{41} \mathrm{~K}^{+}$efflux is also implicated in interleukin (IL)-1 $\beta$ release from immune cells. ${ }^{42}$

\section{Large pore formation}

While the P2X receptor small ion-permeable channels open upon brief stimulation with ATP ( $<1$ second), sustained receptor activation can induce membrane permeabilization or formation of a large pore. ${ }^{6}$ The $\mathrm{P} 2 \mathrm{X} 7$ receptor, corresponding to the formerly named $\mathrm{P} 2 \mathrm{Z}$ receptor in the immune cells, ${ }^{43}$ is the prototypic ionotropic receptor with such an unusual functional property. The pore formation can be experimentally demonstrated by intracellular accumulation of fluorescent cationic dyes, such as YO-PRO1 (molecular weight
[MW]: $375 \mathrm{Da}$ ) and ethidium (MW: $314 \mathrm{Da}$ ), or alternatively by progressive increase in the permeability to positively charged organic cations, such as N-methyl-D-glucamine (MW: $195 \mathrm{Da}$ ). To date, the pore-forming property has been also reported for the $\mathrm{P} 2 \mathrm{X} 2, \mathrm{P} 2 \mathrm{X} 4, \mathrm{P} 2 \mathrm{X} 2 / 3$, and $\mathrm{P} 2 \mathrm{X} 2 / 5$ receptors, although less frequently or consistently in some cases. $^{15,44-46}$

Evidence exists to suggest that the $\mathrm{P} 2 \mathrm{X} 7$ receptor-dependent pore is mediated by separate $\mathrm{P} 2 \mathrm{X} 7$ receptor-interacting protein(s). In this aspect, the pannexin-1 channel has attracted substantial attention. Several studies have shown that the pannexin-1 channel inhibitor, carbenoxolone, and the mimetic peptide, ${ }^{10} \mathrm{Panx}$, can strongly suppress the pore formation without affecting the small ion channel in HEK293 cells heterologously expressing the $\mathrm{P} 2 \mathrm{X} 7$ receptors and in macrophages endogenously expressing the $\mathrm{P} 2 \mathrm{X} 7$ receptors. ${ }^{47,48}$ The P2X7 receptor-dependent dye uptake was virtually abolished in astrocytes from the pannexin-1 knockout (KO) mice. ${ }^{49}$ Intriguingly, however, there was no significant change in the $\mathrm{P} 2 \mathrm{X} 7$ receptor-dependent dye uptake in macrophages from the pannexin-1 KO mice. ${ }^{50}$ The pannexin-1 channel, when expressed alone in HEK293 cells and activated in hypotonic solutions, permeated only the small ions but not the fluorescent dye and, in addition, it had no or very mild modulation of $\mathrm{P} 2 \mathrm{X} 7$ receptor-dependent dye uptake when coexpressed with the mouse $\mathrm{P} 2 \mathrm{X} 7$ receptors in HEK293 cells. ${ }^{51}$ The pannex-1 channel has been shown to make no detectable contribution to the pore formation following activation of the P2X2 receptor heterologously expressed in HEK293 cells ${ }^{52}$ and the P2X4 receptor endogenously expressed in microglia. ${ }^{53}$ These results thus disfavor the idea that the pannexin-1 forms the pore. Mutation of the completely conserved glycine residue in the P2X2 (Gly $\left.{ }^{342}\right), \mathrm{P} 2 \mathrm{X} 4\left(\mathrm{Gly}^{347}\right)$, and P2X7 $\left(\mathrm{Gly}^{345}\right)$ receptors to residues with different side-chains and thus physiochemical properties increased, decreased, or completely abolished pore formation. ${ }^{44,45,54}$ These remarkable and contrasting mutational effects on pore dynamics, together with location of such a residue within the TM2 helix and being extracellular to the gating hinge during channel opening, ${ }^{22,55}$ support the notion that the pore is intrinsic to the $\mathrm{P} 2 \mathrm{X}$ receptors.

Regardless of the underlying mechanisms, studies have shown that the $\mathrm{P} 2 \mathrm{X} 7$ receptor-dependent pore formation is important in mediating ATP signaling in several physiological and pathophysiological functions, such as lymphocyte death, ${ }^{56}$ microglial proliferation, ${ }^{54,57}$ and chronic neuropathic and inflammatory pain. ${ }^{48}$ The functional role of the pore associated with the other $\mathrm{P} 2 \mathrm{X}$ receptors is still unclear. 


\section{Signaling complexes}

There is also growing evidence to indicate that the $\mathrm{P} 2 \mathrm{X}$ receptors interact with structurally and functionally diverse proteins and lipids to form ATP signaling complexes. For example, in addition to the pore formation, sustained activation of the $\mathrm{P} 2 \mathrm{X} 7$ receptors induces dramatic changes in cell morphology such as microvesicle shedding and membrane blebbing. ${ }^{58-61}$ While the microvesicle shedding was previously shown to mediate ATP-induced IL- $1 \beta$ release from immune cells,${ }^{59}$ formation of multivesicular bodies and exosome release of IL-1 $\beta$ is suggested as the underlying mechanism in a more recent study. ${ }^{61}$ The irreversible membrane blebbing disrupts the membrane integrity, leading to cell death. ${ }^{58,60}$ Furthermore, activation of the $\mathrm{P} 2 \mathrm{X} 7$ receptors in microglia has been proposed to induce formation of a $\mathrm{Ca}^{2+}$ independent signaling complex and changes of the microglial cytoskeleton to attenuate microglial phagocytosis. ${ }^{62} \mathrm{~A}$ recent study has shown that a neuronal signaling complex containing the $\mathrm{P} 2 \mathrm{X} 7$ receptors, pannexin- 1 channels, and caspases is responsible for inflammation-induced enteric neuron death. ${ }^{63} \mathrm{~A}$ number of $\mathrm{P} 2 \mathrm{X} 7$ receptor-interacting proteins have been identified, and several such interacting proteins have been shown to impose significant functional modulation of the P2X7 receptors. ${ }^{47,64-66}$ For example, upon prolonged activation, the $\mathrm{P} 2 \mathrm{X} 7$ receptor became dephosphorylated at $\mathrm{Tyr}^{343}$ by receptor protein tyrosine phosphatase, resulting in reduction in $\mathrm{P} 2 \mathrm{X} 7$ receptor currents and delay in membrane blebbing. ${ }^{64}$ The $\mathrm{Ca}^{2+}$ sensor, calmodulin $(\mathrm{CaM})$, interacts with the rat $\mathrm{P} 2 \mathrm{X} 7$ receptor via a CaM-binding motif in the $\mathrm{C}$-terminus to form a signaling complex in a receptor activation- and $\mathrm{Ca}^{2+}$-dependent manner and thereby confer $\mathrm{Ca}^{2+}$-dependent facilitation of the receptor activity and membrane blebbing ${ }^{66}$ The P2X7 receptor functional properties such as the agonist sensitivity and functional roles in inducing such as the pore formation and IL- $1 \beta$ release are strongly modulated by lipids. ${ }^{67}$

Other P2X receptors also form ATP signaling complexes. For example, the P2X1 receptors endogenously expressed in smooth muscles and heterologously expressed in HEK293 cells have been shown to associate with cholesterolor flotillin-rich lipid rafts and cytoskeleton, and such associations are crucial in regulating the $\mathrm{P} 2 \mathrm{X} 1$ receptor ion channel functions and its role in mediating arterial vasoconstriction. ${ }^{68-70}$ The neuronal $\mathrm{Ca}^{2+}$ sensor, VILIP1, interacts with the P2X2 receptor to form a signaling complex in a receptor activationand $\mathrm{Ca}^{2+}$-dependent manner and thereby modulates the ATP sensitivity, surface expression, and mobility of the $\mathrm{P} 2 \mathrm{X} 2$ receptor. $^{71}$ The $\mathrm{P} 2 \mathrm{X} 2, \mathrm{P} 2 \mathrm{X} 2 / 3$, and $\mathrm{P} 2 \mathrm{X} 4$ receptors interact with $\mathrm{nACh}$ and $\mathrm{GABA}_{\mathrm{A} / \mathrm{C}}$ receptors, resulting in a mutual functional inhibition, ${ }^{72-77}$ which may be involved in modulating synaptic strengthening. ${ }^{78}$ The P2X 4 receptor function is subject to modulation by phosphoinositides through direct interactions. ${ }^{79}$

\section{Physiological roles of $\mathbf{P} 2 \mathbf{X}$ receptors}

The pioneering studies in early 1990 provided the first evidence to show an important role for the P2X receptors in mediating excitatory synaptic transmission in the CNS and PNS. ${ }^{80,81}$ Our understanding of the role of the P2X receptors in mediating ATP signaling was greatly enriched during the following decade as was elegantly reviewed previously. ${ }^{6}$ However, the progress in dissecting contribution of the individual P2X receptors had been hampered by the lack of selective receptor antagonists, which remained largely unchanged until 2000 when the transgenic P2X gene KO mice became available.

\section{Physiological roles of $\mathrm{P} 2 \mathrm{X}$ receptors inferred from $\mathrm{KO}$ mice studies}

$\mathrm{P} 2 \mathrm{X} 1, \mathrm{P} 2 \mathrm{X} 2, \mathrm{P} 2 \mathrm{X} 3, \mathrm{P} 2 \mathrm{X} 4$, and $\mathrm{P} 2 \mathrm{X} 7$ single $\mathrm{KO}$ mice and $\mathrm{P} 2 \mathrm{X} 2$ and $\mathrm{P} 2 \mathrm{X} 3$ double $\mathrm{KO}$ mice have been generated. Studies using these transgenic KO mice have substantiated the long-suspected roles in ATP signaling for specific P2X receptors; for example, $\mathrm{P} 2 \mathrm{X} 1$ receptor in mediating vas deferens contraction evoked by ATP and sympathetic nerve stimulation, ${ }^{35} \mathrm{P} 2 \mathrm{X} 3$ and $\mathrm{P} 2 \mathrm{X} 2 / 3$ receptors in sensory neurons in pain, ${ }^{82,83}$ and $\mathrm{P} 2 \mathrm{X} 7$ receptor in IL-1 $\beta$ release. ${ }^{84}$ Moreover, studies using these $\mathrm{KO}$ mice have revealed more previously unrecognized roles, such as $\mathrm{P} 2 \mathrm{X} 3$ and $\mathrm{P} 2 \mathrm{X} 2 / 3$ receptors in mediating taste transduction, ${ }^{85} \mathrm{P} 2 \mathrm{X} 4$ receptor in flow-induced changes in vascular tone and remodeling, ${ }^{38}$ and $\mathrm{P} 2 \mathrm{X} 7$ receptor in cathepsin release from macrophages. ${ }^{86}$ Many of these studies have been reviewed recently. ${ }^{3}$ Table 1 provides a summary of the physiological functions of the $\mathrm{P} 2 \mathrm{X}$ receptors inferred from the KO mice studies.

\section{Physiological roles of $\mathrm{P} 2 \mathrm{X} 7$ receptors revealed by studies of splicing variants}

A number of splicing variants have been recently identified for the human and mouse $\mathrm{P} 2 \mathrm{X} 7$ receptors, and characterizations of them have shed light on additional physiological roles of the $\mathrm{P} 2 \mathrm{X} 7$ receptors. ${ }^{7-11}$ The human $\mathrm{P} 2 \mathrm{X} 7 \mathrm{~B}$ variant is of particular interest because of its wide tissue distribution and several-fold higher mRNA expression than the P2X7A variant encoding the original and full-length receptor subunit. The P2X7B variant retains an intron between exons 10 and 11 
Table I Physiological functions of P2X receptors inferred from knockout mice studies

\begin{tabular}{|c|c|}
\hline Receptor & Physiological functions \\
\hline P2XI & $\begin{array}{l}\text { Vas deference contraction and male fertility; }{ }^{35} \text { renal microvascular auto-regulation; }{ }^{169} \text { platelet aggregation and thrombosis; }{ }^{: 70} \\
\text { neutrophil chemotaxis }{ }^{171}\end{array}$ \\
\hline $\mathrm{P} 2 \times 2$ & $\begin{array}{l}\text { Enteric neurotransmission and peristalsis in small intestine; }{ }^{172} \text { modulation of excitatory synapses onto interneuron in } \\
\text { hippocampus; } ; 1 \text { skeletal neuromuscular junction formation; }{ }^{173} \text { ATP secretion in taste buds; }{ }^{174} \text { vasopressin release at hypothalamic } \\
\text { neurohypophysial terminals; }{ }^{175} \text { sperm function and male fertility }{ }^{176}\end{array}$ \\
\hline $\mathrm{P} 2 \times 3, \mathrm{P} 2 \times 2 / 3$ & $\begin{array}{l}\text { Inflammatory and neuropathic pain; }{ }^{82,83,96} \text { mechanotransduction in urinary bladder; } ; 2,83,177 \text { enteric neurotransmission and peristalsis } \\
\text { in small intestine; }{ }^{: 78} \text { chemoreception in carotid body; }{ }^{179} \text { temperature sensation; }{ }^{180} \text { taste transduction; } ;{ }^{85} \text { long-term depression }{ }^{181}\end{array}$ \\
\hline $\mathrm{P} 2 \mathrm{X} 4$ & $\begin{array}{l}\text { Long-term potentiation in hippocampus; }{ }^{30,97} \text { flow-induced endothelial } \mathrm{Ca}^{2+} \text { signaling and control of vascular tone and remodeling;, } \\
\text { BDNF release in microglia and neuropathic pain; }{ }^{39} \text { prostaglandin E2 release from tissue-residing macrophages and inflammatory pain }{ }^{101}\end{array}$ \\
\hline $\mathrm{P} 2 \times 7$ & $\begin{array}{l}\text { Interleukin-I } \beta \text { release from immune cells; }{ }^{42,84,103,104} \text { changes in volume and shape of monocytes and lymphocytes and L-selectin } \\
\text { shedding; }{ }^{42} \text { macrophage and microglia death; }{ }^{103,104} \text { mechanic loading-induced prostaglandin E2 release and membrane blebbing in } \\
\text { osteoblasts and osteogenesis, and nuclear factor- } \mathrm{KB} \text { signaling in osetoclast formation; }{ }^{182-185} \text { nicotinamide adenine dinucleotide- } \\
\text { induced T lymphocyte cell death; }{ }^{186} \text { inflammatory and neuropathic pain; } ; 9,163 \text { ATP release and astrocytic intercellular } \\
\mathrm{Ca}^{2+} \text { signaling; } ;{ }^{187} \text { regulation of natural killer T cell function in autoimmune liver injury; }{ }^{188} \text { regulation of exocrine gland } \\
\text { secretion; }{ }^{189,190} \text { release of cathepsins from macrophages }{ }^{86}\end{array}$ \\
\hline
\end{tabular}

Abbreviations: ATP, adenosine triphosphate; BDNF, brain-derived neurotrophic factor.

that introduces a premature stop codon and results in replacement of the last 249 residues in the $\mathrm{C}$-terminus of the P2X7A subunit with different 18 residues. When heterologously expressed in HEK293 cells, the $\mathrm{P} 2 \mathrm{X} 7 \mathrm{~B}$ receptor operated as a $\mathrm{Ca}^{2+}$-permeable ion channel but lacked the pore-forming ability. ${ }^{7}$ Expression of the P2X7B receptor in HEK293 cells increased the endoplasmic reticulum $\mathrm{Ca}^{2+}$ level, activation of transcription factor NFATc1 and intracellular ATP content, and potentiated HEK293 cell proliferation. ${ }^{7}$ Furthermore, P2X7B and P2X7A subunit co-assembly enhanced agonistinduced $\mathrm{Ca}^{2+}$ influx, pore formation, membrane blebbing, and ATP release. These results suggest a role for the P2X7B variant in regulating cell proliferation and $\mathrm{P} 2 \mathrm{X} 7 \mathrm{~A}$-mediated functions. ${ }^{7}$ However, the P2X7B-mediated cell proliferation appears to differ from the above-mentioned microglial proliferation, which is absolutely dependent of the pore-forming ability of the P2X7A receptor. ${ }^{54}$

The $\mathrm{P} 2 \mathrm{X} 7 \mathrm{k}$ is a mouse $\mathrm{P} 2 \mathrm{X} 7$ splicing variant that results from alternative exon 1 and encodes a P2X7 subunit with the $\mathrm{N}$-terminus and intracellular half of the TM1 helix different from the original and full-length $\mathrm{P} 2 \mathrm{X} 7$ a subunit. ${ }^{8}$ When heterologously expressed in HEK293 cells, the P2X7k receptor exhibited a greater sensitivity to BzATP, an ATP analogue, than the $\mathrm{P} 2 \mathrm{X} 7 \mathrm{a}$ receptor and a significant sensitivity to nicotinamide adenine dinucleotide (NAD), and receptor activation induced much more rapid pore formation. ${ }^{8,51}$ The P2X7k variant is mainly expressed in lymphocytes. These results have led to the proposal that the $\mathrm{P} 2 \mathrm{X} 7 \mathrm{k}$ receptor mediates NAD-induced phosphatidylserine flip and cell death that were observed in lymphocytes, but not in macrophages. ${ }^{8,51,87,88}$ The P2X7k has escaped disruption in the Glaxo KO mice generated by inserting a LacZ gene and neomycin cassette (Neo) into exon $1,{ }^{89}$ which may also explain the paradoxical observation $^{90}$ that BzATP-induced phosphatidylserine exposure and pore formation were greater and faster in lymphocytes from the Glaxo KO mice, but not from the Pfizer KO mice generated by inserting a Neo cassette in exon $13 .{ }^{42,84}$

In summary, studies of the recently identified splicing variants reveal additional roles for the $\mathrm{P} 2 \mathrm{X} 7$ receptors and also explain some of the unanticipated results from studies using the existing KO mice. Generation of the truly P2X7 KO mice is desirable to better understand the physiological significance of different variants and clarify the discrepancies; for example, regarding their role in IL-6 generation from macrophage ${ }^{84,89}$ and the ongoing controversy surrounding the $\mathrm{P} 2 \mathrm{X} 7$ receptor expression in CNS neurons. ${ }^{91,92}$

\section{Pathophysiological roles of $\mathbf{P} 2 \mathrm{X}$ receptors}

Steady progress in understanding how alterations in the $\mathrm{P} 2 \mathrm{X}$ receptor expression and function contribute to diseases has been made, largely from studies of rodent disease models in conjunction with using the $\mathrm{KO}$ mice or selective receptor antagonists, and also from genetic linkage analysis of single nucleotide polymorphisms (SNP) to human diseases. A brief discussion is presented below, focusing on the evidence that supports the roles for the $\mathrm{P} 2 \mathrm{X}$ receptors in pain and for the P2X7 receptor in inflammatory diseases and cancers. Table 2 provides a summary of more pathophysiological or diseased conditions associated with the $\mathrm{P} 2 \mathrm{X}$ receptors.

\section{$\mathrm{P} 2 \mathrm{X}$ receptors in pain}

ATP was known to induce pain in humans long before molecular cloning of the receptors. ${ }^{93}$ When tissues are injured and 
Table 2 Pathological or diseased conditions associated with the $\mathrm{P} 2 \mathrm{X}$ receptors

\begin{tabular}{|c|c|}
\hline Receptor & Pathological or disease conditions \\
\hline $\mathrm{P} 2 \mathrm{XI}$ & Thromboembolism; ${ }^{170}$ hypertension ${ }^{191}$ \\
\hline $\mathrm{P} 2 \times 3$, & Inflammatory and neuropathic pain; $; 2,96,138$ cystitis; ${ }^{192}$ \\
\hline $\mathrm{P} 2 \times 2 / 3$ & bone cancer pain ${ }^{141}$ \\
\hline $\mathrm{P} 2 \mathrm{X} 4$ & Neuropathic and inflammatory pain ${ }^{98-101}$ \\
\hline \multirow[t]{9}{*}{$\mathrm{P} 2 \times 7$} & Arthritis, ${ }^{42}$ inflammatory and neuropathic pain, ${ }^{9}, 146,150,163$ \\
\hline & tuberculosis; ${ }^{104,193-195}$ hepatitis; ${ }^{188}$ obstructive \\
\hline & nephropathy; ${ }^{196}$ pulmonary fibrosis; ${ }^{105}$ Huntington's \\
\hline & disease; ${ }^{197}$ Alzheimer's disease; ${ }^{; 98-202}$ glomerulonephritis; ${ }^{203}$ \\
\hline & spinal cord injury; ${ }^{164}$ graft-versus-host disease; ${ }^{204}$ morphine \\
\hline & tolerance ${ }^{205}$ amyotrophic lateral sclerosis; $; 06$ seizure $; 207$ \\
\hline & irritable bowel syndrome; ${ }^{208}$ inflammatory bowel \\
\hline & diseases; ${ }^{63}$ cystitis; ${ }^{209}$ chronic lymphocytic leukemia; ${ }^{106,108,115}$ \\
\hline & mood disorders; ${ }^{210-213}$ ischemic heart disease and stroke $\mathrm{e}^{214}$ \\
\hline
\end{tabular}

inflamed, ATP released from damaged or dying cells depolarizes the sensory neurons to elicit pain. In this context, since molecular identification, the P2X3 has attracted substantial attention because of its highly restricted expression in the sensory neurons. ${ }^{94,95}$ Its role in pain has been subsequently substantiated in studies using P2X3 KO mice; P2X3 deficiency reduces pain behaviors, such as lifting, licking, and biting, evoked by injection of ATP, and inflammatory pain induced by injection of formalin. ${ }^{82,96} \mathrm{P} 2 \mathrm{X} 2 \mathrm{KO}$ mice and $\mathrm{P} 2 \mathrm{X} 2$ and $\mathrm{P} 2 \mathrm{X} 3$ double $\mathrm{KO}$ mice also exhibit significant reduction in formalin-induced inflammatory pain. ${ }^{83}$

The $\mathrm{P} 2 \mathrm{X} 4$ receptor is widely regarded as a neuronal $\mathrm{P} 2 \mathrm{X}$ receptor involved in eg, synaptic plasticity. ${ }^{97}$ However, an early study using the rat model of neuropathic pain induced by spinal nerve ligation (SNL) provided evidence to indicate that the $\mathrm{P} 2 \mathrm{X} 4$ receptor is engaged in chronic neuropathic pain resulting from peripheral nerve injury. More surprisingly, it is the de novo or upregulated expression of the $\mathrm{P} 2 \mathrm{X} 4$ receptor in activated spinal microglia but not neuron that mediates the tactile allodynia. ${ }^{98} \mathrm{P} 2 \mathrm{X} 4 \mathrm{KO}$ mice are insensitive to SNL-induced neuropathic pain experienced by the wild-type littermates. In addition, brain-derived neurotrophic factor (BDNF) release in microglia is completely abolished and BDNF signaling in the spinal cord is impaired in $\mathrm{P} 2 \mathrm{X} 4 \mathrm{KO}$ mice, suggesting that the microglial $\mathrm{P} 2 \mathrm{X} 4$ receptors mediate neuropathic pain through a central inflammatory pathway dependent of BDNF signaling. ${ }^{99}$ Studies have also provided evidence to support a role for the $\mathrm{P} 2 \mathrm{X} 4$ receptor in chronic inflammatory pain. P2X4 KO mice show attenuation or complete loss of tactile allodynia in inflammatory pain induced by injection of inflammatory stimuli such as formalin, carrageenan, and complete Freund's adjuvant (CFA). ${ }^{100,101} \mathrm{P} 2 \mathrm{X} 4$ deficiency prevents inflammatory stimuli-induced production of prostaglandin E2 (PGE2) from macrophages residing in the peripheral tissues. ${ }^{101}$ PGE2 is the major prostaglandin produced during inflammatory responses that induces pain hypersensitivity by sensitizing and overexciting the nociceptive neurons. ${ }^{102}$ In addition, neuropathic and inflammatory pain can be elicited in naive animals by injecting ATP-primed microglia and macrophages, respectively. ${ }^{98,101}$ Thus, the P2X4 receptor contributes to chronic neuropathic and inflammatory pain by mediating different molecular and cellular mechanisms.

The $\mathrm{P} 2 \mathrm{X} 7$ receptor is required for ATP-induced release of proinflammatory IL-1 $\beta$ from microglia and glial-neuron interaction in the brain as well as ATP-induced IL-1 $\beta$ release from macrophages and other immune cells in the peripheral tissues, ${ }^{84,103,104}$ implying a crucial role for the $\mathrm{P} 2 \mathrm{X} 7$ receptor in chronic neuropathic and inflammatory pain. Indeed, the P2X7 KO mice exhibit complete loss of tactile allodynia and thermal hyperalgesia induced by nerve injury and injection of CFA. ${ }^{89}$ Interestingly, a recent genome-wide linkage study has shown that the mice expressing the $\mathrm{P} 2 \mathrm{X} 7$ receptor deficient of inducing the pore formation were less sensitive to chronic neuropathic pain induced by nerve injury than the mice expressing the $\mathrm{P} 2 \mathrm{X} 7$ receptor able to induce the pore formation. ${ }^{48}$ Furthermore, this study has found that within a cohort of patients after mastectomy and a separate cohort of patients suffering from inflammatory disease osteoarthritis, individuals expressing the $\mathrm{P} 2 \mathrm{X} 7$ receptors deficient of pore formation reported a lower amount of pain than those expressing the $\mathrm{P} 2 \mathrm{X} 7$ receptors with the pore-forming ability. ${ }^{48}$ These results suggest that the pore formation rather than the small ion channel opening is key to the role of the P2X7 receptor in determining the sensitivity to chronic neuropathic and inflammatory pain. Such a finding bears importance to rationalizing development of pain therapeutics targeting the $\mathrm{P} 2 \mathrm{X} 7$ receptor and also raises questions such as whether the pore-forming ability is critical in chronic neuropathic and inflammatory pain mediated by the $\mathrm{P} 2 \mathrm{X} 2 / 3$ and $\mathrm{P} 2 \mathrm{X} 4$ receptors.

In summary, the $\mathrm{P} 2 \mathrm{X} 3, \mathrm{P} 2 \mathrm{X} 2 / 3, \mathrm{P} 2 \mathrm{X} 4$ and $\mathrm{P} 2 \mathrm{X} 7$ receptors play an important role in mediating ATP signaling in chronic neuropathic and inflammatory pain, pointing to these $\mathrm{P} 2 \mathrm{X}$ receptors as promising targets for pain therapeutics.

\section{P2X7 receptor in inflammatory diseases}

Altered P2X7 receptor expression and function are causatively associated with numerous inflammatory diseases (Table 2). For example, an early study using the mouse arthritis model induced by monoclonal anti-collagen antibody showed that 
the P2X7 KO mice manifested significant reduction in both incidence and severity of lipopolysaccharide (LPS)-induced swelling in the paws, lesions in joint cartilage, loss of proteoglycan content, and collagen degradation, ${ }^{42}$ supporting a critical role for the $\mathrm{P} 2 \mathrm{X} 7$ receptor in arthritis.

Pulmonary fibrosis is another devastating inflammatory disease currently without effective treatments. Bronchoalveolar lavage fluid from pulmonary fibrosis patients has been found in a recent study to contain a substantially higher level of ATP than that from control. ${ }^{105}$ This study further using the bleomycin-induced lung fibrosis mouse model has shown that inhibition of the $\mathrm{P} 2 \mathrm{X} 7$ receptor using antagonist A740003 or inhibition of the pannexin-1 channel using carbenoxolone and ${ }^{10}$ Panx reduced bleomycininduced ATP release from pulmonary epithelial cells. ${ }^{105}$ The bleomycin-administrated P2X7 KO mice exhibited substantially reduced lung inflammation and lung fibrosis. These results suggest that the $\mathrm{P} 2 \mathrm{X} 7$ receptor and pannexin-1 channel play an important role in mediating ATP signaling in the pathogenesis of lung fibrosis. Another recent study using the mouse experimental colitis model has revealed that the P2X7 receptor and pannexin-1 are critical components of an ATP-signaling complex that contribute to inflammationinduced loss of enteric neurons and progression of inflammatory bowel diseases. ${ }^{63}$

\section{P2X7 receptors in cancers}

Alterations in the expression and function of the $\mathrm{P} 2 \mathrm{X}$ receptors and particularly the $\mathrm{P} 2 \mathrm{X} 7$ receptor have also been documented by numerous studies of a variety of cancerous tissues and cells. ${ }^{10,106-114}$ An early study investigating the human P2X7 receptor in lymphocytes from chronic lymphocytic leukemia (CLL) patients reveals a strong correlation of the P2X7 expression and function with the CLL severity. ${ }^{107}$ In a separate group of CLL patients, there was a threefold greater prevalence of the non-synonymous SNP (ns-SNP) 1513A-C which introduces loss-of-functional E496A mutation in the C-terminus, and higher frequency of the $1513 \mathrm{C}$ allele. ${ }^{108,115}$ Moreover, the P2X7 receptor-dependent dye uptake, detected in lymphocytes from the CLL patients expressing the 1513A/A alleles or the Glu ${ }^{496}$-carrying P2X7 receptor, was reduced by approximately half in lymphocytes expressing the $1513 \mathrm{~A} / \mathrm{C}$ alleles or both the $\mathrm{Glu}^{496}$ - and Ala ${ }^{494}$-carrying $\mathrm{P} 2 \mathrm{X} 7$ receptor subunits, and completely lost in lymphocytes expressing the $1513 \mathrm{C} / \mathrm{C}$ alleles or the $\mathrm{Ala}^{496}$-carrying P2X7 receptor. ${ }^{108}$ Survival for the CLL patients with the 1513A/A alleles was found to be significantly lower than those with the $1513 \mathrm{~A} / \mathrm{C}$ alleles. ${ }^{15}$ Another interesting ns-SNP, 559A-G, was identified in human J6-1 leukemia cells, resulting in N187D mutation in the extracellular domain. ${ }^{106}$ When heterologously expressed in K562 cells void of endogenous $\mathrm{P} 2 \mathrm{X} 7$ expression, the P2X7 mutant receptor is three times less sensitive to ATP than the wild-type receptor. Expression of the mutant receptor accelerated K562 cell proliferation and decreased BzATP-induced apoptosis. Furthermore, the nude mice subcutaneously implanted with K562 cells expressing the N187D mutant receptor produced tumors significantly faster, and the size and weight of the tumors were larger and heavier. Angiogenesis and macrophage infiltration were also elevated in the tumor tissues formed by the cells expressing the mutant receptor. These results provide strong evidence to support a role for the $\mathrm{P} 2 \mathrm{X} 7$ receptor with altered functional properties in determining the pathogenesis and progression of human hematopoietic malignancies such as CLL.

A recent study has shown that the $\mathrm{P} 2 \mathrm{X} 7$ expression is highly expressed in the aggressive human breast cancer cells MDA-MB-435s, and ATP stimulates cell migration and particularly cell invasion. ${ }^{116}$ Such ATP-induced effects were prevented by reducing the $\mathrm{P} 2 \mathrm{X} 7$ expression using small interference RNA or inhibiting the $\mathrm{P} 2 \mathrm{X} 7$ receptor using receptor selective antagonists KN62 and A740003. Furthermore, using a zebrafish metastases model, this study has elegantly demonstrated that the $\mathrm{P} 2 \mathrm{X} 7$ receptor activity is crucial in determining the invasiveness of such breast cancer cells.

Therefore, accumulating evidence indicates the expression and function of the $\mathrm{P} 2 \mathrm{X} 7$ receptors have strong causative relationships to cancer cell proliferation, migration, and invasion. The P2X7 receptor may represent a novel diagnostics biomarker and a promising therapeutic target for cancers.

\section{Experimental $\mathbf{P} 2 \mathbf{X}$ receptor antagonists and therapeutic potential}

As mentioned above, the $\mathrm{P} 2 \mathrm{X}$ receptor research was hindered by the lack of selective antagonists for a long time. Early efforts to search for selective receptor antagonists, largely focusing on structural modification of the existing antagonists, eg, suramin, to improve the specificity, and also detailed characterization of the antagonists implied by previous studies, such as KN-62 and Brilliant blue G (BBG), led to identification of several potent and selective $\mathrm{P} 2 \mathrm{X}$ receptor antagonists, which have been proved as useful experimental tools aiding in-vitro and even in-vivo studies, as highlighted later. However, many of them have poor physiochemical properties that thus predict poor pharmacokinetics and limited therapeutic potential. The growing evidence 
that supports the importance of the $\mathrm{P} 2 \mathrm{X}$ receptors in health and disease has triggered interest in developing therapeutic P2X receptor antagonists. There have been a number of high-throughput screening (HTS) drug discovery programs driven by pharmaceutical companies, mainly focusing on the $\mathrm{P} 2 \mathrm{X} 3, \mathrm{P} 2 \mathrm{X} 2 / 3$, and $\mathrm{P} 2 \mathrm{X} 7$ receptors. Such efforts have led to discovery of numerous novel potent and selective P2X receptor antagonists with drug-like properties. Many of these compounds have been shown to exhibit weak or no activity at a large number of G-protein-coupled receptors, enzymes, transporters, and other ion channels. Discussed below are the pharmacological properties of the well characterized P2X receptor antagonists and some recently developed drug-like $\mathrm{P} 2 \mathrm{X}$ receptor antagonists, and example in-vitro and in-vivo studies and clinical trials of $\mathrm{P} 2 \mathrm{X}$ receptor antagonists. Table 3 provides a summary of the pharmacological properties of the main $\mathrm{P} 2 \mathrm{X}$ receptor antagonists that are commercially available. Figure 2 shows the chemical structures of representative drug-like $\mathrm{P} 2 \mathrm{X}$ receptor antagonists that have been recently developed.

\section{$\mathrm{P} 2 \mathrm{X}$ receptor selective antagonists}

NF023, NF279, and NF449 (Table 3) were developed by structural modification of suramin, a generic P2 receptor antagonist (Table 3), with significantly improved specificity towards the $\mathrm{P} 2 \mathrm{X}$ receptors and particularly the $\mathrm{P} 2 \mathrm{X} 1$ receptor. The antagonism is competitive. NF023 inhibits the P2X1 receptor with a half-maximal inhibitory concentration $\left(\mathrm{IC}_{50}\right)$ of 210-240 nM, and is less potent at the other P2X receptors with $\mathrm{IC}_{50}$ of $9-29 \mu \mathrm{M}$ at the $\mathrm{P} 2 \mathrm{X} 3$ receptor, $1.4 \mu \mathrm{M}$ at the $\mathrm{P} 2 \mathrm{X} 2 / 3$ receptor, $>50 \mu \mathrm{M}$ at the $\mathrm{P} 2 \mathrm{X} 2$ receptor and $>>100 \mu \mathrm{M}$ at the $\mathrm{P} 2 \mathrm{X} 4$ receptor. ${ }^{117} \mathrm{NF} 279$ antagonizes the $\mathrm{P} 2 \mathrm{X} 1$ receptor, with an $\mathrm{IC}_{50}$ of $19-50 \mathrm{nM},{ }^{118,119}$ and far less potent at the $\mathrm{P} 2 \mathrm{X} 2, \mathrm{P} 2 \mathrm{X} 3, \mathrm{P} 2 \mathrm{X} 4$, and $\mathrm{P} 2 \mathrm{X} 7$ receptors, with $\mathrm{IC}_{50}$ of $0.8 \mu \mathrm{M}, 1.6 \mu \mathrm{M},>300 \mu \mathrm{M}$, and $2.8 \mu \mathrm{M}$, respectively. NF449 is more potent than NF023 and N279 in inhibiting the $\mathrm{P} 2 \mathrm{X} 1$ receptor, with an $\mathrm{IC}_{50}$ of $0.3 \mathrm{nM}$. It is equally potent at the $\mathrm{P} 2 \mathrm{X} 1 / 5$ receptor, with an $\mathrm{IC}_{50}$ of $0.7 \mathrm{nM}$, whereas three or more orders of magnitude higher concentrations are required for inhibiting the other $\mathrm{P} 2 \mathrm{X}$ receptors, with $\mathrm{IC}_{50}$ of $47 \mu \mathrm{M}$, $1.8 \mu \mathrm{M}, 0.3 \mu \mathrm{M}$, and $>300 \mu \mathrm{M}$ at the $\mathrm{P} 2 \mathrm{X} 2, \mathrm{P} 2 \mathrm{X} 3, \mathrm{P} 2 \mathrm{X} 2 / 3$, and $\mathrm{P} 2 \mathrm{X} 4$ receptors, respectively. ${ }^{120-122}$

Diinosine pentaphosphate (IP5I) (Table 3) is a potent $\mathrm{P} 2 \mathrm{X} 1$ receptor antagonist, with an $\mathrm{IC}_{50}$ of $3 \mathrm{nM}$, exhibiting surmountable antagonism at $\leq 100 \mathrm{nM}$ and a more complex action at higher concentrations. ${ }^{123}$ IP5I also blocks the P2X3 receptor but at much higher concentrations with an $\mathrm{IC}_{50}$ of $2.8 \mu \mathrm{M}$. It does not however inhibit the $\mathrm{P} 2 \mathrm{X} 2 / 3$ receptor even at $30 \mu \mathrm{M} ;{ }^{124}$ such selectivity between the $\mathrm{P} 2 \mathrm{X} 3$ and $\mathrm{P} 2 \mathrm{X} 2 / 3$ receptors results from preferential binding to the desensitized state of the $\mathrm{P} 2 \mathrm{X} 3$ receptor. ${ }^{125}$

TNP (2', 3'-O-(2,4,6-trinitrophenyl)-substituted)-ATP (Table 3 ) represents a highly potent antagonist for inhibiting the $\mathrm{P} 2 \mathrm{X} 1, \mathrm{P} 2 \mathrm{X} 1 / 5, \mathrm{P} 2 \mathrm{X} 3$, and $\mathrm{P} 2 \mathrm{X} 2 / 3$ receptors with $\mathrm{IC}_{50}$ of $0.4-7.0 \mathrm{nM} .{ }^{126}$ It is a competitive antagonist when examined at the $\mathrm{P} 2 \mathrm{X} 2 / 3$ receptor $^{127}$ or a slowly desensitizing $\mathrm{P} 2 \mathrm{X} 2-3$ chimera receptor in which the N-terminus and TM1 helix of the $\mathrm{P} 2 \mathrm{X} 3$ subunit is replaced with the corresponding parts of the P2X2 subunit. ${ }^{128}$ TNP-ATP inhibits the P2X2, P2X4, and $\mathrm{P} 2 \mathrm{X} 7$ receptors, but it is much less effective with $\mathrm{IC}_{50}$ of $\geq 2 \mu \mathrm{M}^{126,129}$

There are several $\mathrm{P} 2 \mathrm{X} 7$ receptor antagonists, some of which display striking species differences. For example, the CaMK-II inhibitor KN-62 (Table 3) and its inactive analogue $\mathrm{KN}-04$ are the first potent human $\mathrm{P} 2 \mathrm{X} 7$ receptor antagonists. ${ }^{130,131}$ KN-62 antagonizes agonist-induced $\mathrm{Ca}^{2+}$ influx and dye uptake with $\mathrm{IC}_{50}$ of $\sim 40 \mathrm{nM}$ and $100 \mathrm{nM}$ in HEK293 cells expressing the human P2X7 receptor, but even at $1 \mu \mathrm{M}$ it has no effect on the responses mediated by the rat $\mathrm{P} 2 \mathrm{X} 7$ receptor. The inhibition is competitive. To prove the pharmacokinetic properties, several series of KN-62 derivatives have been tested, ${ }^{132-134}$ leading to identification of several phenylpiperazine derivatives with approximately ten-fold greater potency. However, these studies also indicate the isoquinolinesulfonyl group to be essential for the potent antagonism, suggesting that identification of KN-62-related P2X7 receptor antagonists with desirable pharmacokinetics remains a challenging if not impossible mission.

$\mathrm{BBG}$ (Table 3 ) is a potent and selective $\mathrm{P} 2 \mathrm{X} 7$ receptor antagonist. ${ }^{12,135}$ It is particularly potent at the rat $\mathrm{P} 2 \mathrm{X} 7$ receptor, with an $\mathrm{IC}_{50}$ of $\sim 10 \mathrm{nM},>100$-fold less effective at the rat $\mathrm{P} 2 \mathrm{X} 2$ receptor, with an $\mathrm{IC}_{50}$ of $1.4 \mu \mathrm{M}$, and inactive at the rat $\mathrm{P} 2 \mathrm{X} 1, \mathrm{P} 2 \mathrm{X} 1 / 5, \mathrm{P} 2 \mathrm{X} 3, \mathrm{P} 2 \mathrm{X} 2 / 3$, and $\mathrm{P} 2 \mathrm{X} 4$ receptors, with $\mathrm{IC}_{50}$ of $>5 \mu \mathrm{M}$. BBG is also potent in inhibiting the human $\mathrm{P} 2 \mathrm{X} 7$ receptor, with an $\mathrm{IC}_{50}$ of $270 \mathrm{nM}$, but it is less discriminative among the human $\mathrm{P} 2 \mathrm{X}$ receptors as it blocks the human $\mathrm{P} 2 \mathrm{X} 5$ receptor, with an $\mathrm{IC}_{50}$ of $500 \mathrm{nM}$. It is much less potent at the human $\mathrm{P} 2 \mathrm{X} 4$ receptor, with an $\mathrm{IC}_{50}$ of $3.2 \mu \mathrm{M}$, and ineffective at the human $\mathrm{P} 2 \mathrm{X} 1$ and $\mathrm{P} 2 \mathrm{X} 2 / 3$ receptors, with $\mathrm{IC}_{50}$ of $>5 \mu \mathrm{M}$. The antagonism of BBG at the $\mathrm{P} 2 \mathrm{X} 7$ receptors is insurmountable.

\section{Recently developed $\mathrm{P} 2 \mathrm{X}$ receptor antagonists}

RO-1 (or RO-0437626) is a selective P2X1 receptor antagonist (Table 3 and Figure 2). ${ }^{136,137}$ It inhibits the human 
Table 3 Pharmacological properties of commercially available P2X antagonists

\begin{tabular}{|c|c|c|c|}
\hline Antagonist & Target receptor: $I C_{50}$ & Further information or comments & References \\
\hline \multirow[t]{2}{*}{ Suramin } & P2XI: I $\mu \mathrm{M} ; \mathrm{P} 2 \mathrm{XI} / 5:$ I.6 $\mu \mathrm{M} ; \mathrm{P} 2 \mathrm{X} 2:$ & P2X7: $80 \mu \mathrm{M}$; P2X4: >500 $\mu \mathrm{M}$; active & $215-217$ \\
\hline & $10 \mu \mathrm{M} ; \mathrm{P} 2 \times 3: 3 \mu \mathrm{M} ;$ P2X5: 2.4-4.0 $\mu \mathrm{M}$ & at $\mathrm{P}_{2} \mathrm{Y}_{2}: 29 \mu \mathrm{M}^{\mathrm{b}}$ and particularly $\mathrm{P} 2 \mathrm{Y}_{1 \mathrm{I}}$ & \\
\hline \multirow[t]{2}{*}{ PPADS } & $\mathrm{P} 2 \mathrm{XI}: \leq \mathrm{I} \mu \mathrm{M} ; \mathrm{P} 2 \mathrm{XI} / 5: 0.6 \mu \mathrm{M} ; \mathrm{P} 2 \mathrm{X} 2:$ & P2X7: $\sim 60 \mu \mathrm{M}, 1.3 \mu \mathrm{M}(\mathrm{r})$; P2X4: & $215,217,218$ \\
\hline & $2-5 \mu \mathrm{M} ; \mathrm{P} 2 \times 2 / 3: \sim 5 \mu \mathrm{M} ; \mathrm{P} 2 \times 3: 1.5 \mu \mathrm{M}$ & 10-27, $\geq 500 \mu \mathrm{M}$ (r); active $\mathrm{P}_{2} \mathrm{Y}_{2}$-like: $900 \mu \mathrm{M}$ & \\
\hline \multirow[t]{2}{*}{ NF023 } & $P 2 X 1: 210(h), 240 \mathrm{nM}(r)^{b}$ & $\mathrm{P} 2 \mathrm{X} 2:>50 \mu \mathrm{M}^{\mathrm{b}} ; \mathrm{P} 2 \times 2 / 3:$ I.4 $\mu \mathrm{M}^{\mathrm{b}}$ & 117 \\
\hline & & P2X3: I.6-8.5 (r), $29 \mu \mathrm{M}(\mathrm{h})^{\mathrm{b}} ; \mathrm{P} 2 \times 4:>>100 \mu \mathrm{M}^{\mathrm{b}}$ & \\
\hline \multirow[t]{2}{*}{ NFI57 } & $\mathrm{P} 2 \mathrm{XI}: 63 \mathrm{nM}(\mathrm{h}), 80 \mathrm{nM}(\mathrm{r})^{\mathrm{b}}$ & P2X2: I 38 nMb; P2X3: 800 nM (h) $)^{b}$ P2X4: >I $\mu M^{b}$ & 216 \\
\hline & & $\mathrm{P} 2 \mathrm{X7}:>30 \mu \mathrm{M}^{\mathrm{b}}$; active at $\mathrm{P} 2 \mathrm{Y}_{11}: 460 \mathrm{nM}^{\mathrm{b}}$ & \\
\hline \multirow[t]{2}{*}{ NF279 } & $\mathrm{P} 2 \mathrm{XI}: 19-50 \mathrm{nM}^{\mathrm{b}}$ & P2X2: 800 nM"; P2X3: I.6 $\mu M^{b}$ & 118,119 \\
\hline & & $\mathrm{P} 2 \mathrm{X} 4:>300 \mu \mathrm{M}^{\mathrm{b}} ; \mathrm{P} 2 \times 7: 2.8 \mu \mathrm{M}^{\mathrm{b}}$ & \\
\hline \multirow[t]{2}{*}{ NF449 } & $\mathrm{P} 2 \mathrm{XI}: 0.3 \mathrm{nM}^{\mathrm{b}}$ & P2XI/5: 0.7 nM'; P2X2: $47 \mu M^{b} ; \mathrm{P} 2 X 2 / 3: 300$ nM"b; & $120-122,219$ \\
\hline & & P2X3: I.8 $\mu \mathrm{M}^{\mathrm{b}} ; \mathrm{P} 2 \mathrm{X} 4:>300 \mu \mathrm{M}^{\mathrm{b}} ; \mathrm{P} 2 \mathrm{X} 7: 40 \mu \mathrm{M}^{\mathrm{b}}$ & \\
\hline \multirow[t]{2}{*}{ NFIIO } & $\mathrm{P} 2 \mathrm{XI}: 201 \mathrm{nM}$; P2X2/3: 55 nM; & P2X2: $6.2 \mu \mathrm{M}^{\mathrm{b}} ; \mathrm{P} 2 X 4:>100 \mu \mathrm{M}^{\mathrm{b}} ; \mathrm{P} 2 X 7:>30 \mu \mathrm{M}^{\mathrm{b}}$ & 220 \\
\hline & P2X3: $90 \mathrm{nM}^{\mathrm{b}}$ & & \\
\hline \multirow[t]{2}{*}{ IP5I } & $\mathrm{P} 2 \mathrm{XI}: 3 \mathrm{nM}^{\mathrm{b}}$ & $\mathrm{P} 2 \mathrm{X} 2:>>30 \mu \mathrm{M}^{\mathrm{b}}$; P2X2/3: $>30 \mu \mathrm{M}^{\mathrm{b}} ; \mathrm{P} 2 \mathrm{X} 3:$ & 123,124 \\
\hline & & $2.8 \mu \mathrm{M}^{\mathrm{b}}$; facilitation of $\mathrm{P} 2 \mathrm{X} 4$ receptor responses & \\
\hline \multirow[t]{2}{*}{ TNP-ATP } & $\mathrm{P} 2 \mathrm{XI}: 6 \mathrm{nM} ; \mathrm{P} 2 \mathrm{XI} / 5: 0.4 \mathrm{nM}^{\mathrm{b}}$ & P2X2: $2 \mu M^{b} ;$ P2X4: $15 \mu M^{b} ;$ P2X7: $>30 \mu M^{b}$ & 126,129 \\
\hline & $\mathrm{P} 2 \times 2 / 3: 7$ nM; $\mathrm{P} 2 \times 3: 0.9 \mathrm{nM}^{\mathrm{b}}$ & & \\
\hline RO-I & $\mathrm{P} 2 \mathrm{XI}: 3 \mu \mathrm{M}^{\mathrm{a}}$ & $\mathrm{P} 2 \times 2, \mathrm{P} 2 \times 2 / 3, \mathrm{P} 2 \mathrm{X} 3:>100 \mu \mathrm{M}^{\mathrm{a}}$ & 136 \\
\hline \multirow[t]{2}{*}{ A-3 $|749|$} & $\mathrm{P} 2 \times 3, \mathrm{P} 2 \times 2 / 3: 15-170 \mathrm{nM}^{\mathrm{b}}$ & $\mathrm{P} 2 \mathrm{XI}, \mathrm{P} 2 \mathrm{X} 2, \mathrm{P} 2 \mathrm{X} 4$ and $\mathrm{P} 2 \mathrm{X} 7: \mathrm{K}_{\mathrm{i}} \geq 2 \mu \mathrm{M}^{\mathrm{a}}$ & 138 \\
\hline & $\left(K_{i}: 4-20 \mathrm{nM}^{\mathrm{b}}, 9-92 \mathrm{nM}^{\mathrm{a}}\right)$ & & \\
\hline RO-3 & P2X3: $125 \mathrm{nM}^{\mathrm{a}}$ & $\mathrm{P} 2 \mathrm{X} 2 / 3: 2 \mu \mathrm{M}^{\mathrm{a}}$ & 137 \\
\hline RO-5I & $\mathrm{P} 2 \times 2 / 3: 5$ nMa; $\mathrm{P} 2 \times 3: 2$ nM"a & $\mathrm{P} 2 \mathrm{X} 1, \mathrm{P} 2 \mathrm{X} 2, \mathrm{P} 2 \mathrm{X} 4, \mathrm{P} 2 \times 5, \mathrm{P} 2 \times 7:>10 \mu \mathrm{M}^{\mathrm{a}}$ & 140 \\
\hline Spinorpin & P2X3: $8.3 \mathrm{pM}^{\mathrm{b}}$ & P2XI: $>10 \mu \mathrm{M}^{\mathrm{b}} ; \mathrm{P} 2 \times 7:>10 \mu \mathrm{M}^{\mathrm{d}}$ & 221 \\
\hline 5-BDBD & $\mathrm{P} 2 \times 4: 500 \mathrm{nM}$ & & 222 \\
\hline \multirow[t]{2}{*}{$\mathrm{KN}-62$} & P2X7: $40-130 \mathrm{nM}(\mathrm{h})^{\mathrm{b}}, 86 \mathrm{nM}(\mathrm{rm})^{\mathrm{b}}$ & hP2X7 in lymphocytes: 13 nMa, 13 nMd; & $|30| ,3|, 2| 8,223,224$ \\
\hline & $23-320 \mathrm{nM}(\mathrm{h})^{\mathrm{d}}, 130 \mathrm{nM}(\mathrm{gp})^{\mathrm{d}}, 10 \mathrm{nM}(\mathrm{d})^{\mathrm{d}}$ & rP2X7: $>>\mid \mu M^{b},>>3 \mu M^{d} ;$ P2X4: $>>3 \mu M^{b}$ & \\
\hline \multirow[t]{3}{*}{ BBG } & $\mathrm{P} 2 \mathrm{X} 7: \sim 10 \mathrm{nM}(\mathrm{r})^{\mathrm{b}}, 270 \mathrm{nM}(\mathrm{h})^{\mathrm{b}}$ & $\mathrm{P} 2 \mathrm{X} 5: 500 \mathrm{nM}^{\mathrm{b}} ; \mathrm{P} 2 \mathrm{XI}:>5 \mu \mathrm{M}^{\mathrm{b}} ; \mathrm{P} 2 \mathrm{XI} / 5:>10 \mu \mathrm{M}^{\mathrm{b}}$ & $12,135,2 \mid 8,223$ \\
\hline & I $58 \mathrm{nM}(\mathrm{r})^{\mathrm{d}}, 324 \mathrm{nM}(\mathrm{h})^{\mathrm{d}}, 49 \mathrm{nM}(\mathrm{d})^{\mathrm{d}}$ & P2X2: >I.4 $\mu \mathrm{M}^{\mathrm{b}} ; \mathrm{P} 2 \times 2 / 3: 10 \mu \mathrm{M}^{\mathrm{b}} ; \mathrm{P} 2 \mathrm{X} 3:>10 \mu \mathrm{M}^{\mathrm{b}}$ & \\
\hline & $23 \mathrm{nM}(\mathrm{gp})^{\mathrm{d}}$ & $\mathrm{P} 2 \mathrm{X} 4:>10 \mu \mathrm{M}(\mathrm{r})$ and $3.2 \mu \mathrm{M}(\mathrm{h})^{\mathrm{b}}$ & \\
\hline \multirow[t]{2}{*}{ A-438079 } & P2X7: $126 \mathrm{nM}(\mathrm{h})^{\mathrm{a}}, 32 \mathrm{I} \mathrm{nM}(\mathrm{r})^{\mathrm{a}}$ & P2X7 in THP-I cells: 398 nMe; P2XI, P2X2, P2X2/3, & 146,224 \\
\hline & $493 \mathrm{nM}(\mathrm{h})^{\mathrm{b}}, 200 \mathrm{nM}(\mathrm{h})^{\mathrm{d}}, 297 \mathrm{nM}(\mathrm{rm})^{\mathrm{b}}$ & P2X4: inactive at $100 \mu \mathrm{M}^{\mathrm{a}}$ & \\
\hline A-839977 & P2X7: $20 \mathrm{nM}(\mathrm{h})^{\mathrm{a}}, 42 \mathrm{nM}(\mathrm{r})^{\mathrm{a}}, 150 \mathrm{nM}(\mathrm{m})^{\mathrm{a}}$ & P2X7 in THP-I cells: 3 nM (h) $; 37$ nM (h) ${ }^{\mathrm{e}}$ & 147 \\
\hline \multirow[t]{2}{*}{ A-740003 } & P2X7: $18 \mathrm{nM}(\mathrm{h})^{\mathrm{a}}, 40 \mathrm{nM}(\mathrm{r})^{\mathrm{a}}$ & P2X7 in THP-I cells: $92 \mathrm{nM}(\mathrm{h})^{\mathrm{d}}$; I56 nM (h) ${ }^{\mathrm{e}}$; P2XI, & $148-150$ \\
\hline & & $\mathrm{P} 2 \times 2, \mathrm{P} 2 \times 2 / 3, \mathrm{P} 2 \times 4$ : inactive at $100 \mu \mathrm{M}^{\mathrm{a}}$ & \\
\hline \multirow[t]{2}{*}{ A-804598 } & P2X7: II nM (h) $, 10 \mathrm{nM}(\mathrm{r})^{\mathrm{a}}, 9 \mathrm{nM}(\mathrm{m})^{\mathrm{a}}$ & P2X7 in THP-I cells: 8.1 nM (h) $; 8.5$ nM (h) ${ }^{\mathrm{e}}$; P2XI, & 151 \\
\hline & & $\mathrm{P} 2 \times 2, \mathrm{P} 2 \times 2 / 3, \mathrm{P} 2 \times 4$ : inactive at $100 \mu \mathrm{M}^{\mathrm{a}}$ & \\
\hline \multirow[t]{3}{*}{ AZII 645373} & P2X7: $31 \mathrm{nM} M^{\mathrm{b}}\left(\right.$ or $\left.\mathrm{K}_{\mathrm{i}}=5-20 \mathrm{nM}^{\mathrm{a}, \mathrm{b}, \mathrm{d}}\right)(\mathrm{h})$, & P2X7 in THP-I cells: $90 \mathrm{nM}^{\mathrm{e}}$; rP2X7: $>10 \mu \mathrm{M}^{\mathrm{b}}$ & 153,224 \\
\hline & $23 \mathrm{nM}(\mathrm{rm})^{\mathrm{b}}$ & $\mathrm{P} 2 \mathrm{XI}, \mathrm{P} 2 \times 2, \mathrm{P} 2 \times 3, \mathrm{P} 2 \times 2 / 3, \mathrm{P} 2 \times 4, \mathrm{P} 2 \times 5$ & \\
\hline & & inactive at $10 \mu \mathrm{M}^{\mathrm{b}}$ & \\
\hline \multirow[t]{2}{*}{ AZI0606I20 } & $\mathrm{P} 2 \times 7:<10 \mathrm{nM}(\mathrm{h})^{\mathrm{d}},>10-1000 \mathrm{nM}(\mathrm{r})^{\mathrm{d}}$ & & $156,223,225$ \\
\hline & $58 \mathrm{nM}(\mathrm{gp})^{\mathrm{d}}$ & & \\
\hline
\end{tabular}

Notes: ${ }^{a} \mathrm{C}_{50}$ or $\mathrm{K}_{\mathrm{i}}$ based on measurements of agonist-induced $\mathrm{Ca}^{2+}\left(/ \mathrm{Ba}^{2+}\right)$ influx (or $\mathrm{P} 2 \mathrm{Y}$ receptor-mediated intracellular release); ${ }^{\text {bionic }}$ currents; ${ }^{\mathrm{C}} \mathrm{K}^{+}$efflux; ${ }^{\mathrm{d}} \mathrm{dye}$ uptake; einterleukin-I $\beta$ release.

Abbreviations: $I_{50}$, half-maximal inhibitory concentration; $K_{i}$, equilibrium dissociation constant/binding affinity; $h$, human; rm, rhesus macaque monkey; $d$, dog; $r$, rat; $\mathrm{m}$, mouse; gp, guinea pig.

$\mathrm{P} 2 \mathrm{X} 1$-mediated $\mathrm{Ca}^{2+}$ influx, with a modest $\mathrm{IC}_{50}$ of $3 \mu \mathrm{M}$, and is $>30$-fold less potent at the human P2X2, P2X3, and $\mathrm{P} 2 \mathrm{X} 2 / 3$ receptors, with $\mathrm{IC}_{50}$ of $>100 \mu \mathrm{M}$.

A-317491 represents the first potent and selective druglike $\mathrm{P} 2 \mathrm{X} 3$ and $\mathrm{P} 2 \mathrm{X} 2 / 3$ receptor antagonist (Table 3 and Figure 2). ${ }^{128,138}$ It antagonizes agonist-induced $\mathrm{Ca}^{2+}$ influx with an equilibrium dissociation constant/binding affinity $\left(\mathrm{K}_{\mathrm{i}}\right)$ of 9-92 nM, which is $>200$-fold more potent in comparison with $\mathrm{K}_{\mathrm{i}}$ of $\geq 2 \mu \mathrm{M}$ for inhibiting $\mathrm{Ca}^{2+}$ influx mediated by the $\mathrm{P} 2 \mathrm{X} 1, \mathrm{P} 2 \mathrm{X} 2, \mathrm{P} 2 \mathrm{X} 4$, and $\mathrm{P} 2 \mathrm{X} 7$ receptors. It also inhibits currents mediated by the P2X 3 and $\mathrm{P} 2 \mathrm{X} 2 / 3$ receptors, with $\mathrm{IC}_{50}$ of $15-170 \mathrm{nM}$ or $\mathrm{K}_{\mathrm{i}}$ of 4-20 nM.

RO-3, RO-4, RO-5, and RO51 are all selective P2X3 and $\mathrm{P} 2 \mathrm{X} 2 / 3$ receptor antagonists. ${ }^{137,139-141} \mathrm{RO}-3$ (Table 3 and Figure 2) inhibits the $\mathrm{Ca}^{2+}$ influx mediated by the human $\mathrm{P} 2 \mathrm{X} 3$ and $\mathrm{P} 2 \mathrm{X} 2 / 3$ receptors, with $\mathrm{IC}_{50}$ of $125 \mathrm{nM}$ and 
<smiles>O=C(N[C@H](Cc1cscn1)C(=O)N[C@H](C1CCCCC1)[C@@H](O)[C@@H](O)C1CC1)c1nc2ccccc2[nH]1</smiles>

RO-1<smiles>CC(=O)c1cc(C(=O)O)c(C(=O)O)cc1C(=O)N(Cc1cccc(Oc2ccccc2)c1)[C@@H]1CCCc2ccccc21</smiles><smiles>[R9]O[R6]</smiles><smiles>[R][IH][R]</smiles>

RO-4 (AF-353)
A-317491<smiles>COc1cc(C(C)C)c(Oc2cnc(NC(CO)CO)nc2N)cc1I</smiles>

RO-51<smiles>CC(=O)N1CCN(C[C@@H](C)NC(=O)c2cc3c(-c4ccccc4)nn(C)c3s2)CC1</smiles>

RO-85

B<smiles>Clc1cccc(-c2nnnn2Cc2cccnc2)c1Cl</smiles>

A-438079

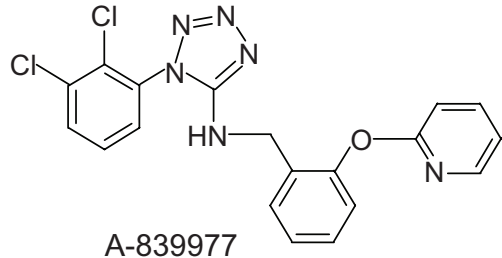

A-839977<smiles>COc1ccc(CC(=O)NC(NC(=NC#N)Nc2cccc3ncccc23)C(C)(C)C)cc1OC</smiles>

A-740003<smiles>Cc1ccc(CC(=O)NC(NC(=NC#N)Nc2cccnc2C)C(C)(C)C)cc1</smiles>

A-759029<smiles>CC(N/C(=N/C#N)Nc1cccc2ncccc12)c1ccccc1</smiles>

A-804598<smiles>O=C(CC12CC3CC(CC(C3)C1)C2)Nc1cccc2nc(NCCNCCO)ccc12</smiles>

AZ10606120<smiles>COC[C@H](O)CN1C(=O)CNN(c2ccc(Cl)c(C(=O)NCC3(O)CCCCCC3)c2)C1=O</smiles>

CE-224535

Figure 2 Chemical structures of recently-developed drug-like P2X receptor antagonists. (A) P2X2/3 and P2X3 selective antagonists, except for RO-I and RO-85 that are $\mathrm{P} 2 \mathrm{XI}$ and $\mathrm{P} 2 \mathrm{X} 3$ selective antagonists respectively. (B) P2X7 selective antagonists.

$2 \mu \mathrm{M}$, respectively, and its actions on other $\mathrm{P} 2 \mathrm{X}$ receptors have not been reported. RO-4 (Figure 2), recently renamed as $\mathrm{AF}-353$, inhibits agonist-induced $\mathrm{Ca}^{2+}$ influx, with $\mathrm{IC}_{50}$ of 3-10 nM and 18-39 nM at the P2X3 and P2X2/3 receptors, respectively. The inhibition is insurmountable. RO-4 is inactive at the $\mathrm{P} 2 \mathrm{X} 1, \mathrm{P} 2 \mathrm{X} 2, \mathrm{P} 2 \mathrm{X} 4, \mathrm{P} 2 \mathrm{X} 5$, and $\mathrm{P} 2 \mathrm{X} 7$ receptors, with $\mathrm{IC}_{50}$ of $>10 \mu \mathrm{M}$. RO-5, recently renamed as AF-792, exhibits similar potency in inhibiting the $\mathrm{Ca}^{2+}$ influx mediated by the $\mathrm{P} 2 \mathrm{X} 3$ and $\mathrm{P} 2 \mathrm{X} 2 / 3$ receptors, with $\mathrm{IC}_{50}$ of 6 and $11 \mathrm{nM}$, respectively. It is inactive in inhibiting 
$\mathrm{Ca}^{2+}$ influx mediated by the P2X1, P2X2, P2X 4, P2X5, and $\mathrm{P} 2 \mathrm{X} 7$ receptors, with $\mathrm{IC}_{50}$ of $>10 \mu \mathrm{M}$. RO-51 (Table 3 and Figure 2) inhibits $\mathrm{Ca}^{2+}$ influx mediated by the $\mathrm{rP} 2 \mathrm{X} 3$ and $\mathrm{hP} 2 \mathrm{X} 2 / 3$ receptors, with $\mathrm{IC}_{50}$ of 2 and $5 \mathrm{nM}$, respectively, and inactive at the $\mathrm{P} 2 \mathrm{X} 1, \mathrm{P} 2 \mathrm{X} 2, \mathrm{P} 2 \mathrm{X} 4, \mathrm{P} 2 \mathrm{X} 5$, and $\mathrm{P} 2 \mathrm{X} 7$ receptors at $10 \mu \mathrm{M}$.

RO-85 (Figure 2) is a selective $\mathrm{P} 2 \mathrm{X} 3$ receptor antagonist inhibiting $\mathrm{Ca}^{2+}$ influx mediated by the rat and human $\mathrm{P} 2 \mathrm{X} 3$ receptors, with $\mathrm{IC}_{50}$ of 32 and $400 \mathrm{nM}$, respectively. ${ }^{142} \mathrm{It}$ is ineffective at the $\mathrm{P} 2 \mathrm{X} 2 / 3$ and other $\mathrm{P} 2 \mathrm{X}$ receptors, with $\mathrm{IC}_{50}$ of $>10 \mu \mathrm{M}$.

A series of tetrazole/triazole-based compounds have been reported as potent, selective, and competitive $\mathrm{P} 2 \mathrm{X} 7$ receptor antagonists. ${ }^{14-146}$ Two tetrazole compounds, A-438079 and A-839977 (Table 3 and Figure 2), have been extensively characterized. ${ }^{146,147}$ A-438079 inhibits BzATP-induced $\mathrm{Ca}^{2+}$ influx and dye uptake in $132 \mathrm{~N} 1$ cells expressing the human P2X7 receptor, with $\mathrm{IC}_{50}$ of 126 and $200 \mathrm{nM}$, respectively, and BzATP-induced IL-1 $\beta$ release in THP-1 cells, with an $\mathrm{IC}_{50}$ of $398 \mathrm{nM}$. It also potently blocks BzATP-induced $\mathrm{Ca}^{2+}$ influx in $132 \mathrm{~N} 1$ cells expressing the rat $\mathrm{P} 2 \mathrm{X} 7$ receptors, with an $\mathrm{IC}_{50}$ of $321 \mathrm{nM}$. However, it is inactive in inhibiting agonist-induced $\mathrm{Ca}^{2+}$ influx in $132 \mathrm{~N} 1$ cells expressing the $\mathrm{P} 2 \mathrm{X} 1, \mathrm{P} 2 \mathrm{X} 2, \mathrm{P} 2 \mathrm{X} 2 / 3$, and $\mathrm{P} 2 \mathrm{X} 4$ receptors at $100 \mu \mathrm{M}$. Similarly, A-839977 is very potent in inhibiting BzATPinduced $\mathrm{Ca}^{2+}$ influx in $1321 \mathrm{~N} 1$ cells expressing human, rat, or mouse $\mathrm{P} 2 \mathrm{X} 7$ receptors, with $\mathrm{IC}_{50}$ of 20,42 , and $150 \mathrm{nM}$, respectively; the inhibition is competitive with pA2 of 8.1 (or $8 \mathrm{nM}$ ). A-839977 blocks BzATP-induced dye uptake and IL-1 $\beta$ release in THP-1 cells, with $\mathrm{IC}_{50}$ of 7 and $37 \mathrm{nM}$, respectively.

A series of cyanoguanidine derivatives have been discovered as potent and selective $\mathrm{P} 2 \mathrm{X} 7$ receptor antagonists, with $\mathrm{IC}_{50}$ of $\sim 100 \mathrm{nM} .^{148-151} \mathrm{~A}-740003, \mathrm{~A}-759029$, and A-804598 represent three of them. A-740003 (Table 3 and Figure 2) inhibits BzATP-induced $\mathrm{Ca}^{2+}$ influx, with $\mathrm{IC}_{50}$ of 18 and $40 \mathrm{nM}$ in $132 \mathrm{~N} 1$ cells expressing the human and rat $\mathrm{P} 2 \mathrm{X} 7$ receptors, respectively, and BzATP-induced dye uptake, with $\mathrm{IC}_{50}$ of 138 and $93 \mathrm{nM}$, respectively. It also prevents BzATP-induced dye uptake and IL-1 $\beta$ release in THP-1 cells, with $\mathrm{IC}_{50}$ s of 92 and $156 \mathrm{nM}$, respectively. A-740003 at $100 \mu \mathrm{M}$ has little or no inhibition of agonistinduced $\mathrm{Ca}^{2+}$ influx in $132 \mathrm{~N} 1$ cells expressing the $\mathrm{P} 2 \mathrm{X} 1$, $\mathrm{P} 2 \mathrm{X} 2, \mathrm{P} 2 \mathrm{X} 2 / 3$, and P2X4 receptors. A-759029 (Figure 2) inhibits BzATP-induced $\mathrm{Ca}^{2+}$ influx in $132 \mathrm{~N} 1$ cells expressing the human and rat $\mathrm{P} 2 \mathrm{X} 7$ receptors, with $\mathrm{IC}_{50}$ of 32 and $40 \mathrm{nM}$, respectively, and it is inactive at the P2X3 and P2X4 receptors at $10 \mu \mathrm{M}$. A-804598 (Table 3 and Figure 2) is most potent among the three compounds. It inhibits BzATP-evoked $\mathrm{Ca}^{2+}$ influx in $1321 \mathrm{~N} 1$ cells expressing the human, rat, and mouse $\mathrm{P} 2 \mathrm{X} 7$ receptors, with $\mathrm{IC}_{50}$ of 11,10 , and $9 \mathrm{nM}$, respectively. The antagonism is competitive with pA2 of 7.7 (or $20 \mathrm{nM}$ ). It is also effective in suppressing BzATP-evoked dye uptake and IL-1 $\beta$ release in THP-1 cells, with $\mathrm{IC}_{50}$ of 8.1 and $8.5 \mathrm{nM}$, respectively. A-840598 at $100 \mu \mathrm{M}$ is inactive in preventing agonist-evoked $\mathrm{Ca}^{2+}$ influx in $132 \mathrm{~N} 1$ cells expressing the P2X1, P2X2, P2X2/3, and $\mathrm{P} 2 \mathrm{X} 4$ receptors.

A series of cyclic imides have been shown as potent, selective, and competitive human $\mathrm{P} 2 \mathrm{X} 7$ antagonists inhibiting BzATP-induced dye uptake, with $\mathrm{pA}_{2}$ of 6.2-7.7 (or 20-630 nM). ${ }^{152}$ One of them, AZ11645373 has been characterized in detail. ${ }^{153}$ AZ1 1645373 inhibits human P2X7 receptor-mediated currents, $\mathrm{Ca}^{2+}$ influx, and dye uptake in HEK293 cells, with an $\mathrm{IC}_{50} / \mathrm{K}_{\mathrm{i}}$ of 5-20 $\mathrm{nM}$ depending on the assays, and ATP-induced release of IL- $1 \beta$ from THP-1 cells, with an $\mathrm{IC}_{50}$ of $90 \mathrm{nM}$. The antagonism becomes largely insurmountable at relatively high concentrations. However, it poorly blocks rat $\mathrm{P} 2 \mathrm{X} 7$ receptor-mediated currents, with an $\mathrm{IC}_{50}$ of $>10 \mu \mathrm{M}$, and has no significant effect on agonist-induced currents mediated by the P2X1, P2X2, $\mathrm{P} 2 \mathrm{X} 3, \mathrm{P} 2 \mathrm{X} 2 / 3, \mathrm{P} 2 \mathrm{X} 4$, and $\mathrm{P} 2 \mathrm{X} 5$ receptors expressed in HEK293 cells at $10 \mu \mathrm{M}$.

A series of adamantane amides has been also identified as potent, selective, and competitive human P2X7 antagonists. ${ }^{154,155}$ One of the most potent compounds inhibits human P2X7 receptor-dependent dye uptake, with $\mathrm{pA}_{2}$ of 8.8 (or $1.6 \mathrm{nM}$ ), but it is ineffective for blocking rat $\mathrm{P} 2 \mathrm{X} 7$ receptor-dependent dye uptake, with $\mathrm{pA}_{2}$ of $<5$ (or $>10 \mu \mathrm{M}$ ). Further efforts to search for human P2X7 receptor antagonists with better pharmacokinetics and also rodent $\mathrm{P} 2 \mathrm{X} 7$ receptor antagonists have led to identification of a compound that inhibits BzATP-induced dye uptake in HEK293 cells expressing the human $\mathrm{P} 2 \mathrm{X} 7$ receptor, and IL-1 $\beta$ release from THP- 1 cells, with $\mathrm{IC}_{50}$ of 10 and $80 \mathrm{nM}$, respectively. However, it is still less effective in blocking BzATP-induced dye uptake in HEK293 cells expressing the rat $\mathrm{P} 2 \mathrm{X} 7$ receptor, with an $\mathrm{IC}_{50}$ of $400 \mathrm{nM}$. This compound is inactive at the $\mathrm{P} 2 \mathrm{X} 1, \mathrm{P} 2 \mathrm{X} 2, \mathrm{P} 2 \mathrm{X} 2 / 3, \mathrm{P} 2 \mathrm{X} 3, \mathrm{P} 2 \mathrm{X} 4$, and P2X5 at $10 \mu \mathrm{M}$. AZ-10606120 (Table 3 and Figure 2), also known as compound-17, is an adamantane amide. ${ }^{67,156}$ It is a potent and noncompetitive $\mathrm{P} 2 \mathrm{X} 7$ receptor antagonist blocking human $\mathrm{P} 2 \mathrm{X} 7$ receptor-dependent dye uptake in HEK293 cells, with an $\mathrm{IC}_{50}$ of $<10 \mathrm{nM}$, and rat P2X7 receptor-dependent dye uptake with reduced potency, with an $\mathrm{IC}_{50}$ of $>10-1000 \mathrm{nM}$. 
A series of 6-azauracil derivatives has been described as potent and selective human $\mathrm{P} 2 \mathrm{X} 7$ receptor antagonists based on the inhibition of BzATP-induced IL-1 $\beta$ release in THP-1 cells. ${ }^{157}$ One of them, CE-224535 (Figure 2), displays good pharmacokinetic and safety profiles in rat, dog, and monkey, and excellent potency in inhibiting ATP-induced dye uptake and IL-1 $\beta$ release in THP-1 cells, with $\mathrm{IC}_{50}$ of 4 and $1 \mathrm{nM}$, respectively. However, it is inactive in inhibiting ATP-induced IL-1 $\beta$ release in murine macrophages.

In summary, a number of potent and selective drug-like $\mathrm{P} 2 \mathrm{X}$ receptor antagonists and particularly those inhibiting the $\mathrm{P} 2 \mathrm{X} 3, \mathrm{P} 2 \mathrm{X} 2 / 3$, and $\mathrm{P} 2 \mathrm{X} 7$ receptors have been developed.

\section{Preclinical studies using rodent disease models}

A majority of newly published drug-like $\mathrm{P} 2 \mathrm{X}$ receptor antagonists, with the exception of a few, suffer one way or another from unsatisfactory pharmacokinetic properties. Nevertheless, preclinical studies using rodent disease models have demonstrated excellent efficacy of several P2X receptor antagonists. For example, the P2X 3 and P2X2/3 receptor antagonist A-317491 is tri-acidic in nature and is predicted to have poor oral bioavailability and high plasma protein binding. ${ }^{158}$ Administration of A-317491 induced concentration-dependent suppression of neuropathic and inflammatory pain in rats. ${ }^{138,159}$ Other P2X3 and $\mathrm{P} 2 \mathrm{X} 2 / 3$ receptor antagonists AF-353 (RO-4) and AF-792 (RO-5) have significantly better pharmacokinetic properties including CNS penetration. ${ }^{140-142,160}$ Systemic administration of AF-353 has been shown to strongly reduce bone cancer pain in rats. ${ }^{141}$ A recent study using AF-353 has shown a role for the $\mathrm{P} 2 \mathrm{X} 3$ and $\mathrm{P} 2 \mathrm{X} 2 / 3$ receptors in bronchoconstriction-induced activation of vagal nodose $\mathrm{C}$-fibers in the lung that may relate to airway allergic responses. ${ }^{161}$ Another study using AF-792 has revealed presynaptic $\mathrm{P} 2 \mathrm{X} 3$ and $\mathrm{P} 2 \mathrm{X} 2 / 3$ receptors in the spinal cord as a central purinergic mechanism regulating the visceral activities, suggesting that spinal $\mathrm{P} 2 \mathrm{X} 3$ and $\mathrm{P} 2 \mathrm{X} 2 / 3$ receptors are therapeutic targets for treatment of overactive bladder. ${ }^{162}$

Studies have shown that administration of the P2X7 receptor antagonists $\mathrm{A}-740003^{150}$ and $\mathrm{A}-438079^{146}$ in rats suppresses chronic neuropathic pain induced by nerve injury and chemotherapy, and inflammatory pain induced by injection of formalin, carrageenan, or CFA. Concomitant injection of A-438079 in the lumbar spinal cord of rats strongly reduced LPS-induced tactile hyperalgesia associated with microglial activation and IL- $1 \beta$ release in the dorsal horn. ${ }^{163}$ These studies support a critical role for the $\mathrm{P} 2 \mathrm{X} 7$ receptor in mediating glia-neuron interactions in determining the sensitivity to chronic pain, and suggest that CNS-penetratable P2X7 receptor antagonists targeting microglial release of IL-1 $\beta$ in pain-enhanced response states is beneficial in alleviating chronic pain.

BBG as a potent and selective rat $\mathrm{P} 2 \mathrm{X} 7$ receptor antagonist has proved useful in revealing previously unrecognized roles in diseases. For example, traumatic spinal cord injury (SCI) is characterized by an acute loss of tissue at the lesion site followed by secondary damage of peri-traumatic tissue due to inflammatory responses induced by persistent release of excessive ATP. Studies using the rat model of thoracic SCI have shown that systemic administration of BBG after SCI significantly prevented inflammation in the tissues surrounding the lesion, prevented injury severity, and accelerated locomotor function recovery, ${ }^{164}$ suggesting that inactivation of the secondary injury mechanisms by targeting the P2X7 receptor may offer a therapeutic opportunity to improve the recovery from SCI.

\section{Clinical trials}

To date, a small number of $\mathrm{P} 2 \mathrm{X}$ receptor antagonists have been tested in clinical trials. ${ }^{165}$ Afferent Pharmaceuticals is conducting Phase 2 clinical studies to assess AF-219, a $\mathrm{P} 2 \mathrm{X} 3$ receptor antagonist, for treatment of osteoarthritic knee pain (ClinicalTrials.gov identifier: NCT01554579), interstitial cystitis/bladder pain (NCT01569438) and chronic cough (NCT01432730). AstraZeneca has recently completed their study of a Phase 2 clinical trial of AZD9056, a P2X7 receptor antagonist, for treatment of rheumatoid arthritis (NCT00520572); the outcome is rather disappointing as this compound failed to bring about significant therapeutic benefits. ${ }^{166}$ AZD9056 has also been in clinical trials for treatment of osteoarthritis, chronic obstructive pulmonary disease, and inflammatory bowel disease. Pfizer terminated their clinical trial of CE-224535, a P2X7 receptor antagonist as mentioned above, against osteoarthritic knee pain because of the lack of efficacy (NCT00418782), and has recently concluded their Phase 2 clinical study of this compound for treatment of rheumatoid arthritis in patients with an inadequate response to methotrexate (NCT00628095), and the data indicate that CE-224535 was not efficacious. ${ }^{167}$ Clearly, further more investigations are needed to understand the contribution of $\mathrm{P} 2 \mathrm{X} 7$ receptors to the rather complex nature of the disease.

\section{Conclusion and future perspective}

Rapid progress has been made in understanding the mammalian P2X receptors in mediating ATP signaling at the 
molecular, cellular and systems level. However, there is still more to be learnt in the coming years. The determination of the crystal structures of the zebrafish $\mathrm{P} 2 \mathrm{X} 4$ receptors in the closed and open states will revolutionize the approaches to studying the mammalian $\mathrm{P} 2 \mathrm{X}$ receptors in the post-structural era. The structure for the mammalian $\mathrm{P} 2 \mathrm{X}$ receptors is highly desirable. Research efforts are still required to elucidate the molecular or structural basis that determines, for example, the remarkable plasticity in the membrane permeability following activation of the $\mathrm{P} 2 \mathrm{X}$ receptors. The importance of a better understanding of the structure-function relationships and the P2X receptor-mediated ATP signaling mechanisms is nicely highlighted by the interesting finding that the pore formation but not the small ion channel is key to the role of the $\mathrm{P} 2 \mathrm{X} 7$ receptors in determining chronic pain sensitivity. ${ }^{48}$ The identity of the native $\mathrm{P} 2 \mathrm{X}$ receptors largely remains speculative. The $\mathrm{P} 2 \mathrm{X}$ transgenic $\mathrm{KO}$ mice and also the increasing availability of potent and selective $\mathrm{P} 2 \mathrm{X}$ receptor antagonists will surely continue to help to define the native $\mathrm{P} 2 \mathrm{X}$ receptors and understand their roles in physiology and pathophysiology. The P2X KO mice studies have provided compelling evidence to support important roles for the $\mathrm{P} 2 \mathrm{X} 3, \mathrm{P} 2 \mathrm{X} 2 / 3, \mathrm{P} 2 \mathrm{X} 4$, and $\mathrm{P} 2 \mathrm{X} 7$ receptors in chronic pain and for the $\mathrm{P} 2 \mathrm{X} 7$ receptors in rheumatoid arthritis, inflammatory bowel disease, and lung fibrosis, which represent the areas full of considerable unmet clinical needs. The failure in a recent extensive attempt to validate the finding that pharmacological blockage of the $\mathrm{P} 2 \mathrm{X} 7$ receptors can improve locomotor function and recovery from $\mathrm{SCI}^{168}$ clearly indicates more preclinical investigations are required. The drug discovery programs and preclinical studies so far have provided strong proof of concept that the $\mathrm{P} 2 \mathrm{X}$ receptors are druggable targets but therapeutic drugs have not yet been successfully generated. The increased structural information will rationalize the drug discovery strategies, including virtual HTS of chemical libraries and de nova design of drug-like compounds, which is expected to increase the efficiency and accelerate the pace of identifying potent and selective human $\mathrm{P} 2 \mathrm{X}$ receptor antagonists for therapeutics. A better understanding of the P2X receptor downstream signaling may offer further opportunity for identification of specific intervention targets and development of effective therapeutics.

In conclusion, the past decade, particularly the past few years, has witnessed a remarkable progression in gaining a mechanistic understanding of the $\mathrm{P} 2 \mathrm{X}$ receptor-mediated ATP signaling in health and disease. Let us hope that the accumulating knowledge from the research bench will bring benefits to the patients on the bedside in the near future.

\section{Acknowledgments}

The author is grateful to the Biotechnology and Biological Science Research Council for research support and to Professor Steven A Baldwin in the Faculty of Biological Sciences, University of Leeds, for providing the structural model of the human $\mathrm{P} 2 \mathrm{X} 7$ receptor.

\section{Disclosure}

The author has no conflict of interest in this work.

\section{References}

1. Burnstock G. Discovery of Purinergic Signalling, the Initial Resistance and Current Explosion of Interest. Br J Pharmacol. 2012;2:238-255.

2. Abbracchio MP, Burnstock G, Verkhratsky A, Zimmermann H. Purinergic signalling in the nervous system: an overview. Trends Neurosci. 2009;32(1):19-29.

3. Surprenant A, North RA. Signaling at purinergic P2X receptors. Annu Rev Physiol. 2009;71:333-359.

4. Burnstock G, Fredholm BB, North RA, Verkhratsky A. The birth and postnatal development of purinergic signalling. Acta Physiol (Oxf). 2010;199(2):93-147.

5. Khakh BS, North RA. P2X receptors as cell-surface ATP sensors in health and disease. Nature. 2006;442(7102):527-532.

6. North RA. Molecular physiology of P2X receptors. Physiol Rev. 2002; 82(4):1013-1067.

7. Adinolfi E, Cirillo M, Woltersdorf R, et al. Trophic activity of a naturally occurring truncated isoform of the $\mathrm{P} 2 \mathrm{X} 7$ receptor. FASEB J. 2010;24(9):3393-3404.

8. Nicke A, Kuan YH, Masin M, et al. A functional P2X7 splice variant with an alternative transmembrane domain 1 escapes gene inactivation in P2X7 knock-out mice. J Biol Chem. 2009;284(38):25813-25822.

9. Cheewatrakoolpong B, Gilchrest H, Anthes JC, Greenfeder S. Identification and characterization of splice variants of the human P2X7 ATP channel. Biochem Biophys Res Commun. 2005;332(1): $17-27$.

10. Feng YH, Li X, Wang L, Zhou L, Gorodeski GI. A truncated P2X7 receptor variant (P2X7-j) endogenously expressed in cervical cancer cells antagonizes the full-length $\mathrm{P} 2 \mathrm{X} 7$ receptor through heterooligomerization. J Biol Chem. 2006;281(25):17228-17237.

11. Masin M, Young C, Lim K, et al. Expression, assembly and function of novel C-terminal truncated variants of the mouse $\mathrm{P} 2 \mathrm{X} 7$ receptor: re-evaluation of P2X7 knockouts. Br J Pharmacol. 2012;165(4):978-993.

12. Bo X, Jiang LH, Wilson HL, et al. Pharmacological and biophysical properties of the human P2X5 receptor. Mol Pharmacol. 2003;63(6):1407-1416.

13. Barrera NP, Ormond SJ, Henderson RM, Murrell-Lagnado RD, Edwardson JM. Atomic force microscopy imaging demonstrates that $\mathrm{P} 2 \mathrm{X} 2$ receptors are trimers but that $\mathrm{P} 2 \mathrm{X} 6$ receptor subunits do not oligomerize. J Biol Chem. 2005;280(11):10759-10765.

14. Ormond SJ, Barrera NP, Qureshi OS, Henderson RM, Edwardson JM, Murrell-Lagnado RD. An uncharged region within the $\mathrm{N}$ terminus of the P2X6 receptor inhibits its assembly and exit from the endoplasmic reticulum. Mol Pharmacol. 2006;69(5):1692-1700.

15. Compan V, Ulmann L, Stelmashenko O, Chemin J, Chaumont S, Rassendren F. P2X2 and P2X5 subunits define a new heteromeric receptor with P2X7-like properties. J Neurosci. 2012;32(12):4284-4296.

16. Nicke A, Baumert HG, Rettinger J, et al. $P 2 X 1$ and $P 2 X 3$ receptors form stable trimers: a novel structural motif of ligand-gated ion channels. EMBO J. 1998;17(11):3016-3028. 
17. Jiang LH, Kim M, Spelta V, Bo X, Surprenant A, North RA. Subunit arrangement in P2X receptors. $J$ Neurosci. 2003;23(26): 8903-8910.

18. Wilkinson WJ, Jiang LH, Surprenant A, North RA. Role of ectodomain lysines in the subunits of the heteromeric $\mathrm{P} 2 \mathrm{X} 2 / 3$ receptor. Mol Pharmacol. 2006;70(4):1159-1163.

19. Marquez-Klaka B, Rettinger J, Bhargava Y, Eisele T, Nicke A. Identification of an intersubunit cross-link between substituted cysteine residues located in the putative ATP binding site of the P2X1 receptor. J Neurosci. 2007;27(6):1456-1466.

20. Marquez-Klaka B, Rettinger J, Nicke A. Inter-subunit disulfide crosslinking in homomeric and heteromeric P2X receptors. Eur Biophys $J$. 2009;38(3):329-338.

21. Kawate T, Michel JC, Birdsong WT, Gouaux E. Crystal structure of the ATP-gated P2X(4) ion channel in the closed state. Nature. 2009;460(7255):592-598.

22. Hattori M, Gouaux E. Molecular mechanism of ATP binding and ion channel activation in P2X receptors. Nature. 2012;485(7397): 207-212.

23. Browne LE, Jiang LH, North RA. New structure enlivens interest in P2X receptors. Trends Pharmacol Sci. 2010;31(5):229-237.

24. Evans RJ. Structural interpretation of $\mathrm{P} 2 \mathrm{X}$ receptor mutagenesis studies on drug action. Br J Pharmacol. 2010;161(5):961-971.

25. Roger S, Mei ZZ, Baldwin JM, et al. Single nucleotide polymorphisms that were identified in affective mood disorders affect ATPactivated P2X7 receptor functions. J Psychiatr Res. 2010;44(6): 347-355.

26. Bradley HJ, Baldwin JM, Goli GR, et al. Residues 155 and 348 contribute to the determination of $\mathrm{P} 2 \mathrm{X} 7$ receptor function via distinct mechanisms revealed by single-nucleotide polymorphisms. J Biol Chem. 2011;286(10):8176-8187.

27. Gonzales EB, Kawate T, Gouaux E. Pore architecture and ion sites in acid-sensing ion channels and P2X receptors. Nature. 2009;460(7255):599-604

28. Egan TM, Khakh BS. Contribution of calcium ions to P2X channel responses. J Neurosci. 2004;24(13):3413-3420.

29. Wang X, Kim SU, van Breemen C, McLarnon JG. Activation of purinergic $\mathrm{P} 2 \mathrm{X}$ receptors inhibits $\mathrm{P} 2 \mathrm{Y}-$-mediated $\mathrm{Ca} 2+$ influx in human microglia. Cell Calcium. 2000;27(4):205-212.

30. Baxter AW, Choi SJ, Sim JA, North RA. Role of P2X4 receptors in synaptic strengthening in mouse CA1 hippocampal neurons. Eur $J$ Neurosci. 2011;34(2):213-220.

31. Khakh BS, Gittermann D, Cockayne DA, Jones A. ATP modulation of excitatory synapses onto interneurons. J Neurosci. 2003; 23(19):7426-7437.

32. Zhang X, Chen Y, Wang C, Huang LY. Neuronal somatic ATP release triggers neuron-satellite glial cell communication in dorsal root ganglia. Proc Natl Acad Sci U S A. 2007;104(23):9864-9869.

33. Lalo U, Andrew J, Palygin O, Pankratov Y. Ca2+-dependent modulation of GABAA and NMDA receptors by extracellular ATP: implication for function of tripartite synapse. Biochem Soc Trans. 2009;37(Pt 6): 1407-1411.

34. Pankratov Y, Lalo U, Krishtal OA, Verkhratsky A. P2X receptors and synaptic plasticity. Neuroscience. 2009;158(1):137-148.

35. Mulryan K, Gitterman DP, Lewis CJ, et al. Reduced vas deferens contraction and male infertility in mice lacking P2X1 receptors. Nature. 2000;403(6765):86-89.

36. Povstyan OV, Harhun MI, Gordienko DV. Ca2+ entry following P2X receptor activation induces IP3 receptor-mediated $\mathrm{Ca} 2+$ release in myocytes from small renal arteries. $\mathrm{Br} J$ Pharmacol. 2011;162(7):1618-1638.

37. Amobi NI, Guillebaud J, Smith IC. Perspective on the role of P2Xpurinoceptor activation in human vas deferens contractility. Exp Physiol. 2012;97(5):583-602.

38. Yamamoto K, Sokabe T, Matsumoto T, et al. Impaired flow-dependent control of vascular tone and remodeling in P2X4-deficient mice. Nat Med. 2006;12(1):133-137.
39. Adinolfi E, Callegari MG, Cirillo M, et al. Expression of the P2X7 receptor increases the $\mathrm{Ca} 2+$ content of the endoplasmic reticulum, activates NFATc1, and protects from apoptosis. $J$ Biol Chem. 2009;284(15):10120-10128.

40. Hill LM, Gavala ML, Lenertz LY, Bertics PJ. Extracellular ATP may contribute to tissue repair by rapidly stimulating purinergic receptor X7-dependent vascular endothelial growth factor release from primary human monocytes. J Immunol. 2010;185(5):3028-3034.

41. Chen Y, Zhang X, Wang C, Li G, Gu Y, Huang LY. Activation of P2X7 receptors in glial satellite cells reduces pain through downregulation of P2X3 receptors in nociceptive neurons. Proc Natl Acad Sci U S A. 2008;105(43):16773-16778.

42. Labasi JM, Petrushova N, Donovan C, et al. Absence of the P2X7 receptor alters leukocyte function and attenuates an inflammatory response. J Immunol. 2002;168(12):6436-6445.

43. Surprenant A, Rassendren F, Kawashima E, North RA, Buell G. The cytolytic $\mathrm{P} 2 \mathrm{Z}$ receptor for extracellular ATP identified as a $\mathrm{P} 2 \mathrm{X}$ receptor (P2X7). Science. 1996;272(5262):735-738.

44. Khakh BS, Bao XR, Labarca C, Lester HA. Neuronal P2X transmittergated cation channels change their ion selectivity in seconds. Nat Neurosci. 1999;2(4):322-330.

45. Virginio C, MacKenzie A, Rassendren FA, North RA, Surprenant A. Pore dilation of neuronal P2X receptor channels. Nat Neurosci. 1999;2(4):315-321.

46. Eickhorst AN, Berson A, Cockayne D, Lester HA, Khakh BS. Control of $\mathrm{P} 2 \mathrm{X}(2)$ channel permeability by the cytosolic domain. J Gen Physiol. 2002;120(2):119-131.

47. Pelegrin P, Surprenant A. Pannexin-1 mediates large pore formation and interleukin-1beta release by the ATP-gated $\mathrm{P} 2 \mathrm{X} 7$ receptor. EMBO J. 2006;25(21):5071-5082.

48. Sorge RE, Trang T, Dorfman R, et al. Genetically determined P2X7 receptor pore formation regulates variability in chronic pain sensitivity. Nat Med. 2012;18(4):595-599.

49. Scemes E, Spray DC. Extracellular K(+) and Astrocyte Signaling via Connexin and Pannexin Channels. Neurochem Res. 2012. [Epub ahead of print].

50. Qu Y, Misaghi S, Newton K, et al. Pannexin-1 is required for ATP release during apoptosis but not for inflammasome activation. J Immunol. 2011;186(11):6553-6561.

51. Xu XJ, Boumechache M, Robinson LE, et al. Splice-variants of the $\mathrm{P} 2 \mathrm{X} 7$ receptor reveal differential agonist-dependence and functional coupling with pannexin-1. J Cell Sci. 2012. [Epub ahead of print].

52. Chaumont S, Khakh BS. Patch-clamp coordinated spectroscopy shows $\mathrm{P} 2 \mathrm{X} 2$ receptor permeability dynamics require cytosolic domain rearrangements but not Panx-1 channels. Proc Natl Acad Sci U S A. 2008;105(33):12063-12068.

53. Bernier LP, Ase AR, Boue-Grabot E, Seguela P. P2X4 receptor channels form large noncytolytic pores in resting and activated microglia. Glia. 2012;60(5):728-737.

54. Monif M, Reid CA, Powell KL, Smart ML, Williams DA. The P2X7 receptor drives microglial activation and proliferation: a trophic role for P2X7R pore. J Neurosci. 2009;29(12):3781-3791.

55. Fujiwara Y, Keceli B, Nakajo K, Kubo Y. Voltage- and [ATP]dependent gating of the P2X(2) ATP receptor channel. J Gen Physiol. 2009;133(1):93-109.

56. Le Stunff H, Auger R, Kanellopoulos J, Raymond MN. The Pro-451 to Leu polymorphism within the C-terminal tail of $\mathrm{P} 2 \mathrm{X} 7$ receptor impairs cell death but not phospholipase D activation in murine thymocytes. J Biol Chem. 2004;279(17):16918-16926.

57. Bianco F, Ceruti S, Colombo A, et al. A role for P2X7 in microglial proliferation. J Neurochem. 2006;99(3):745-758.

58. Virginio C, MacKenzie A, North RA, Surprenant A. Kinetics of cell lysis, dye uptake and permeability changes in cells expressing the rat P2X7 receptor. J Physiol. 1999;519 Pt 2:335-346.

59. MacKenzie A, Wilson HL, Kiss-Toth E, Dower SK, North RA, Surprenant A. Rapid secretion of interleukin-1beta by microvesicle shedding. Immunity. 2001;15(5):825-835. 
60. Mackenzie AB, Young MT, Adinolfi E, Surprenant A. Pseudoapoptosis induced by brief activation of ATP-gated P2X7 receptors. J Biol Chem. 2005;280(40):33968-33976.

61. Qu Y, Franchi L, Nunez G, Dubyak GR. Nonclassical IL-1 beta secretion stimulated by $\mathrm{P} 2 \mathrm{X} 7$ receptors is dependent on inflammasome activation and correlated with exosome release in murine macrophages. J Immunol. 2007;179(3):1913-1925.

62. Fang KM, Yang CS, Sun SH, Tzeng SF. Microglial phagocytosis attenuated by short-term exposure to exogenous ATP through $\mathrm{P} 2 \mathrm{X}$ receptor action. J Neurochem. 2009;111(5):1225-1237.

63. Gulbransen BD, Bashashati M, Hirota SA, et al. Activation of neuronal P2X7 receptor-pannexin-1 mediates death of enteric neurons during colitis. Nat Med. 2012;18(4):600-604.

64. Kim M, Jiang LH, Wilson HL, North RA, Surprenant A. Proteomic and functional evidence for a $\mathrm{P} 2 \mathrm{X} 7$ receptor signalling complex. EMBOJ. 2001;20(22):6347-6358.

65. Wilson HL, Wilson SA, Surprenant A, North RA. Epithelial membrane proteins induce membrane blebbing and interact with the $\mathrm{P} 2 \mathrm{X} 7$ receptor C terminus. J Biol Chem. 2002;277(37):34017-34023.

66. Roger S, Pelegrin P, Surprenant A. Facilitation of P2X7 receptor currents and membrane blebbing via constitutive and dynamic calmodulin binding. J Neurosci. 2008;28(25):6393-6401.

67. Michel AD, Fonfria E. Agonist potency at P2X7 receptors is modulated by structurally diverse lipids. Br J Pharmacol. 2007;152(4):523-537.

68. Vial C, Evans RJ. Disruption of lipid rafts inhibits P2X1 receptormediated currents and arterial vasoconstriction. J Biol Chem. 2005;280(35):30705-30711.

69. Allsopp RC, Lalo U, Evans RJ. Lipid raft association and cholesterol sensitivity of P2X1-4 receptors for ATP: chimeras and point mutants identify intracellular amino-terminal residues involved in lipid regulation of P2X1 receptors. J Biol Chem. 2010;285(43):32770-32777.

70. Lalo U, Roberts JA, Evans RJ. Identification of human P2X1 receptorinteracting proteins reveals a role of the cytoskeleton in receptor regulation. J Biol Chem. 2011;286(35):30591-30599.

71. Chaumont $\mathrm{S}$, Compan V, Toulme E, et al. Regulation of $\mathrm{P} 2 \mathrm{X} 2$ receptors by the neuronal calcium sensor VILIP1. Sci Signal. 2008;1(41):ra8.

72. Xia R, Mei ZZ, Milligan C, Jiang LH. Inhibitory interaction between P2X4 and GABA(C) rho1 receptors. Biochem Biophys Res Commun. 2008;375(1):38-43.

73. Khakh BS, Zhou X, Sydes J, Galligan JJ, Lester HA. State-dependent cross-inhibition between transmitter-gated cation channels. Nature. 2000;406(6794):405-410.

74. Boue-Grabot E, Emerit MB, Toulme E, Seguela P, Garret M. Crosstalk and co-trafficking between rho1/GABA receptors and ATP-gated channels. J Biol Chem. 2004;279(8):6967-6975.

75. Boue-Grabot E, Toulme E, Emerit MB, Garret M. Subunit-specific coupling between gamma-aminobutyric acid type $\mathrm{A}$ and $\mathrm{P} 2 \mathrm{X} 2$ receptor channels. J Biol Chem. 2004;279(50):52517-52525.

76. Toulme E, Blais D, Leger C, et al. An intracellular motif of P2X(3) receptors is required for functional cross-talk with GABA(A) receptors in nociceptive DRG neurons. J Neurochem. 2007;102(4): 1357-1368.

77. Jo YH, Donier E, Martinez A, Garret M, Toulme E, Boue-Grabot E. Cross-talk between $\mathrm{P} 2 \mathrm{X} 4$ and gamma-aminobutyric acid, type A receptors determines synaptic efficacy at a central synapse. J Biol Chem. 2011;286(22):19993-20004.

78. Jo YH, Boue-Grabot E. Interplay between ionotropic receptors modulates inhibitory synaptic strength. Commun Integr Biol. 2011;4(6): 706-709.

79. Bernier LP, Ase AR, Chevallier S, et al. Phosphoinositides regulate P2X4 ATP-gated channels through direct interactions. J Neurosci. 2008;28(48):12938-12945.

80. Evans RJ, Derkach V, Surprenant A. ATP mediates fast synaptic transmission in mammalian neurons. Nature. 1992;357(6378):503-505.

81. Edwards FA, Gibb AJ, Colquhoun D. ATP receptor-mediated synaptic currents in the central nervous system. Nature. 1992; 359(6391):144-147.
82. Cockayne DA, Hamilton SG, Zhu QM, et al. Urinary bladder hyporeflexia and reduced pain-related behaviour in P2X3-deficient mice. Nature. 2000;407(6807):1011-1015.

83. Cockayne DA, Dunn PM, Zhong Y, et al. P2X2 knockout mice and $\mathrm{P} 2 \mathrm{X} 2 / \mathrm{P} 2 \mathrm{X} 3$ double knockout mice reveal a role for the $\mathrm{P} 2 \mathrm{X} 2$ receptor subunit in mediating multiple sensory effects of ATP. J Physiol. 2005;567(Pt 2):621-639.

84. Solle M, Labasi J, Perregaux DG, et al. Altered cytokine production in mice lacking $\mathrm{P} 2 \mathrm{X}(7)$ receptors. J Biol Chem. 2001;276(1):125-132.

85. Finger TE, Danilova V, Barrows J, et al. ATP signaling is crucial for communication from taste buds to gustatory nerves. Science. 2005;310(5753):1495-1499.

86. Lopez-Castejon G, Theaker J, Pelegrin P, Clifton AD, Braddock M, Surprenant A. P2X(7) receptor-mediated release of cathepsins from macrophages is a cytokine-independent mechanism potentially involved in joint diseases. J Immunol. 2010;185(4):2611-2619.

87. Seman M, Adriouch S, Scheuplein F, et al. NAD-induced T cell death: ADP-ribosylation of cell surface proteins by ART2 activates the cytolytic P2X7 purinoceptor. Immunity. 2003;19(4):571-582.

88. Hong S, Schwarz N, Brass A, et al. Differential regulation of P2X7 receptor activation by extracellular nicotinamide adenine dinucleotide and ecto-ADP-ribosyltransferases in murine macrophages and T cells. J Immunol. 2009;183(1):578-592.

89. Chessell IP, Hatcher JP, Bountra C, et al. Disruption of the P2X7 purinoceptor gene abolishes chronic inflammatory and neuropathic pain. Pain. 2005;114(3):386-396.

90. Taylor SR, Gonzalez-Begne M, Sojka DK, et al. Lymphocytes from P2X7-deficient mice exhibit enhanced P2X7 responses. J Leukoc Biol. 2009;85(6):978-986.

91. Sanchez-Nogueiro J, Marin-Garcia P, Miras-Portugal MT. Characterization of a functional P2X(7)-like receptor in cerebellar granule neurons from P2X(7) knockout mice. FEBS Lett. 2005;579(17):3783-3788.

92. Anderson CM, Nedergaard M. Emerging challenges of assigning P2X7 receptor function and immunoreactivity in neurons. Trends Neurosci. 2006;29(5):257-262.

93. Bleehen T, Keele CA. Observations on the algogenic actions of adenosine compounds on the human blister base preparation. Pain. 1977;3(4):367-377.

94. Chen CC, Akopian AN, Sivilotti L, Colquhoun D, Burnstock G, Wood JN. A P2X purinoceptor expressed by a subset of sensory neurons. Nature. 1995;377(6548):428-431.

95. Lewis C, Neidhart S, Holy C, North RA, Buell G, Surprenant A. Coexpression of $\mathrm{P} 2 \mathrm{X} 2$ and $\mathrm{P} 2 \mathrm{X} 3$ receptor subunits can account for ATPgated currents in sensory neurons. Nature. 1995;377(6548):432-435.

96. Souslova V, Cesare P, Ding Y, et al. Warm-coding deficits and aberrant inflammatory pain in mice lacking $\mathrm{P} 2 \mathrm{X} 3$ receptors. Nature. 2000;407(6807):1015-1017.

97. Sim JA, Chaumont S, Jo J, et al. Altered hippocampal synaptic potentiation in P2X4 knock-out mice. J Neurosci. 2006;26(35):9006-9009.

98. Tsuda M, Shigemoto-Mogami Y, Koizumi S, et al. P2X4 receptors induced in spinal microglia gate tactile allodynia after nerve injury. Nature. 2003;424(6950):778-783.

99. Ulmann L, Hatcher JP, Hughes JP, et al. Up-regulation of P2X4 receptors in spinal microglia after peripheral nerve injury mediates BDNF release and neuropathic pain. J Neurosci. 2008;28(44):11263-11268.

100. Tsuda M, Kuboyama K, Inoue T, Nagata K, Tozaki-Saitoh H, Inoue K. Behavioral phenotypes of mice lacking purinergic $\mathrm{P} 2 \mathrm{X} 4$ receptors in acute and chronic pain assays. Mol Pain. 2009;5:28.

101. Ulmann L, Hirbec H, Rassendren F. P2X4 receptors mediate PGE2 release by tissue-resident macrophages and initiate inflammatory pain. EMBO J. 2010;29(14):2290-2300.

102. Samad TA, Sapirstein A, Woolf CJ. Prostanoids and pain: unraveling mechanisms and revealing therapeutic targets. Trends Mol Med. 2002;8(8):390-396.

103. Brough D, Le Feuvre RA, Iwakura Y, Rothwell NJ. Purinergic (P2X7) receptor activation of microglia induces cell death via an interleukin-1independent mechanism. Mol Cell Neurosci. 2002;19(2):272-280. 
104. Le Feuvre RA, Brough D, Iwakura Y, Takeda K, Rothwell NJ. Priming of macrophages with lipopolysaccharide potentiates P2X7-mediated cell death via a caspase-1-dependent mechanism, independently of cytokine production. J Biol Chem. 2002;277(5):3210-3218.

105. Riteau N, Gasse P, Fauconnier L, et al. Extracellular ATP is a danger signal activating $\mathrm{P} 2 \mathrm{X} 7$ receptor in lung inflammation and fibrosis. Am J Respir Crit Care Med. 2010;182(6):774-783.

106. Chong JH, Zheng GG, Ma YY, et al. The hyposensitive N187D P2X7 mutant promotes malignant progression in nude mice. $J$ Biol Chem. 2010;285(46):36179-36187.

107. Adinolfi E, Melchiorri L, Falzoni S, et al. P2X7 receptor expression in evolutive and indolent forms of chronic B lymphocytic leukemia. Blood. 2002;99(2):706-708.

108. Wiley JS, Dao-Ung LP, Gu BJ, et al. A loss-of-function polymorphic mutation in the cytolytic $\mathrm{P} 2 \mathrm{X} 7$ receptor gene and chronic lymphocytic leukaemia: a molecular study. Lancet. 2002;359(9312):1114-1119.

109. Greig AV, Linge C, Healy V, et al. Expression of purinergic receptors in non-melanoma skin cancers and their functional roles in A431 cells. J Invest Dermatol. 2003;121(2):315-327.

110. Wang Q, Wang L, Feng YH, Li X, Zeng R, Gorodeski GI. P2X7 receptor-mediated apoptosis of human cervical epithelial cells. Am J Physiol Cell Physiol. 2004;287(5):C1349-C1358.

111. Coutinho-Silva R, Stahl L, Cheung KK, et al. P2X and P2Y purinergic receptors on human intestinal epithelial carcinoma cells: effects of extracellular nucleotides on apoptosis and cell proliferation. Am J Physiol Gastrointest Liver Physiol. 2005;288(5):G1024-G1035.

112. Dardano A, Falzoni S, Caraccio N, et al. 1513A $>$ C polymorphism in the $\mathrm{P} 2 \mathrm{X} 7$ receptor gene in patients with papillary thyroid cancer: correlation with histological variants and clinical parameters. J Clin Endocrinol Metab. 2009;94(2):695-698.

113. Gu LQ, Li FY, Zhao L, et al. Association of XIAP and P2X7 receptor expression with lymph node metastasis in papillary thyroid carcinoma. Endocrine. 2010;38(2):276-282.

114. Adinolfi E, Raffaghello L, Giuliani AL, et al. Expression of P2X7 receptor increases in vivo tumor growth. Cancer Res. 2012;72(12): 2957-2969.

115. Thunberg U, Tobin G, Johnson A, et al. Polymorphism in the P2X7 receptor gene and survival in chronic lymphocytic leukaemia. Lancet. 2002;360(9349):1935-1939.

116. Jelassi B, Chantome A, Alcaraz-Perez F, et al. P2X(7) receptor activation enhances SK3 channels- and cystein cathepsin-dependent cancer cells invasiveness. Oncogene. 2011;30(18):2108-2122.

117. Soto F, Lambrecht G, Nickel P, Stuhmer W, Busch AE. Antagonistic properties of the suramin analogue NF023 at heterologously expressed P2X receptors. Neuropharmacology. 1999;38(1):141-149.

118. Klapperstuck M, Buttner C, Nickel P, Schmalzing G, Lambrecht G, Markwardt F. Antagonism by the suramin analogue NF279 on human $\mathrm{P} 2 \mathrm{X}(1)$ and $\mathrm{P} 2 \mathrm{X}(7)$ receptors. Eur J Pharmacol. 2000;387(3):245-252.

119. Rettinger J, Schmalzing G, Damer S, Muller G, Nickel P, Lambrecht G. The suramin analogue NF279 is a novel and potent antagonist selective for the P2X(1) receptor. Neuropharmacology. 2000;39(11): 2044-2053.

120. Braun K, Rettinger J, Ganso M, et al. NF449: a subnanomolar potency antagonist at recombinant rat P2X1 receptors. Naunyn Schmiedebergs Arch Pharmacol. 2001;364(3):285-290.

121. Kassack MU, Braun K, Ganso M, et al. Structure-activity relationships of analogues of NF449 confirm NF449 as the most potent and selective known P2X1 receptor antagonist. Eur J Med Chem. 2004;39(4):345-357.

122. Rettinger J, Braun K, Hochmann H, et al. Profiling at recombinant homomeric and heteromeric rat $\mathrm{P} 2 \mathrm{X}$ receptors identifies the suramin analogue NF449 as a highly potent P2X1 receptor antagonist. Neuropharmacology. 2005;48(3):461-468.

123. King BF, Liu M, Pintor J, Gualix J, Miras-Portugal MT, Burnstock G. Diinosine pentaphosphate (IP5I) is a potent antagonist at recombinant rat P2X1 receptors. Br J Pharmacol. 1999;128(5):981-988.
124. Dunn PM, Liu M, Zhong Y, King BF, Burnstock G. Diinosine pentaphosphate: an antagonist which discriminates between recombinant $\mathrm{P} 2 \mathrm{X}(3)$ and $\mathrm{P} 2 \mathrm{X}(2 / 3)$ receptors and between two $\mathrm{P} 2 \mathrm{X}$ receptors in rat sensory neurones. Br J Pharmacol. 2000;130(6): 1378-1384.

125. Ford KK, Matchett M, Krause JE, Yu W. The P2X3 antagonist P1, P5-di[inosine-5'] pentaphosphate binds to the desensitized state of the receptor in rat dorsal root ganglion neurons. J Pharmacol Exp Ther. 2005;315(1):405-413.

126. Virginio C, Robertson G, Surprenant A, North RA. Trinitrophenylsubstituted nucleotides are potent antagonists selective for P2X1, $\mathrm{P} 2 \mathrm{X} 3$, and heteromeric P2X2/3 receptors. Mol Pharmacol. 1998;53(6):969-973.

127. Burgard EC, Niforatos W, van Biesen T, et al. Competitive antagonism of recombinant $\mathrm{P} 2 \mathrm{X}(2 / 3)$ receptors by $2^{\prime}, 3^{\prime}-\mathrm{O}-(2,4,6-$ trinitrophenyl) adenosine $5^{\prime}$-triphosphate (TNP-ATP). Mol Pharmacol. 2000;58(6):1502-1510.

128. Neelands TR, Burgard EC, Uchic ME, et al. 2', 3'-O-(2,4,6,trinitrophenyl)ATP and A-317491 are competitive antagonists at a slowly desensitizing chimeric human $\mathrm{P} 2 \mathrm{X} 3$ receptor. Br J Pharmacol. 2003;140(1):202-210.

129. Surprenant A, Schneider DA, Wilson HL, Galligan JJ, North RA. Functional properties of heteromeric $\mathrm{P} 2 \mathrm{X}(1 / 5)$ receptors expressed in HEK cells and excitatory junction potentials in guinea-pig submucosal arterioles. J Auton Nerv Syst. 2000;81(1-3):249-263.

130. Gargett CE, Wiley JS. The isoquinoline derivative KN-62 a potent antagonist of the P2Z-receptor of human lymphocytes. Br J Pharmacol. 1997;120(8):1483-1490.

131. Humphreys BD, Virginio C, Surprenant A, Rice J, Dubyak GR. Isoquinolines as antagonists of the P2X7 nucleotide receptor: high selectivity for the human versus rat receptor homologues. Mol Pharmacol. 1998;54(1):22-32.

132. Baraldi PG, del Carmen Nunez M, Morelli A, Falzoni S, Di Virgilio F, Romagnoli R. Synthesis and biological activity of $\mathrm{N}$-arylpiperazinemodified analogues of $\mathrm{KN}-62$, a potent antagonist of the purinergic P2X7 receptor. J Med Chem. 2003;46(8):1318-1329.

133. Lee GE, Joshi BV, Chen W, et al. Synthesis and structure-activity relationship studies of tyrosine-based antagonists at the human P2X7 receptor. Bioorg Med Chem Lett. 2008;18(2):571-575.

134. Romagnoli R, Baraldi PG, Carrion MD, et al. From tyrosine to glycine: synthesis and biological activity of potent antagonists of the purinergic P2X7 receptor. J Med Chem. 2007;50(15):3706-3715.

135. Jiang LH, Mackenzie AB, North RA, Surprenant A. Brilliant blue G selectively blocks ATP-gated rat P2X(7) receptors. Mol Pharmacol. 2000;58(1):82-88

136. Jaime-Figueroa S, Greenhouse R, Padilla F, Dillon MP, Gever JR, Ford AP. Discovery and synthesis of a novel and selective druglike P2X(1) antagonist. Bioorg Med Chem Lett. 2005;15(13): 3292-3295.

137. Ford AP, Gever JR, Nunn PA, et al. Purinoceptors as therapeutic targets for lower urinary tract dysfunction. Br J Pharmacol. 2006;147 Suppl 2: S132-S143.

138. Jarvis MF, Burgard EC, McGaraughty S, et al. A-317491, a novel potent and selective non-nucleotide antagonist of $\mathrm{P} 2 \mathrm{X} 3$ and $\mathrm{P} 2 \mathrm{X} 2 / 3$ receptors, reduces chronic inflammatory and neuropathic pain in the rat. Proc Natl Acad Sci U SA. 2002;99(26):17179-17184.

139. Carter DS, Alam M, Cai H, et al. Identification and SAR of novel diaminopyrimidines. Part 1: The discovery of RO-4, a dual P2X(3)/ P2X(2/3) antagonist for the treatment of pain. Bioorg Med Chem Lett. 2009;19(6):1628-1631.

140. Jahangir A, Alam M, Carter DS, et al. Identification and SAR of novel diaminopyrimidines. Part 2: The discovery of RO-51, a potent and selective, dual $\mathrm{P} 2 \mathrm{X}(3) / \mathrm{P} 2 \mathrm{X}(2 / 3)$ antagonist for the treatment of pain. Bioorg Med Chem Lett. 2009;19(6):1632-1635.

141. Kaan TK, Yip PK, Patel S, et al. Systemic blockade of P2X3 and $\mathrm{P} 2 \mathrm{X} 2 / 3$ receptors attenuates bone cancer pain behaviour in rats. Brain. 2010;133(9):2549-2564. 
142. Brotherton-Pleiss CE, Dillon MP, Ford AP, et al. Discovery and optimization of RO-85, a novel drug-like, potent, and selective P2X3 receptor antagonist. Bioorg Med Chem Lett. 2010;20(3):1031-1036.

143. Nelson DW, Gregg RJ, Kort ME, et al. Structure-activity relationship studies on a series of novel, substituted 1-benzyl-5-phenyltetrazole P2X7 antagonists. J Med Chem. 2006;49(12):3659-3666.

144. Carroll WA, Kalvin DM, Perez Medrano A, et al. Novel and potent 3-(2,3-dichlorophenyl)-4-(benzyl)-4H-1,2,4-triazole P2X7 antagonists. Bioorg Med Chem Lett. 2007;17(14):4044-4048.

145. Florjancic AS, Peddi S, Perez-Medrano A, et al. Synthesis and in vitro activity of 1-(2,3-dichlorophenyl)-N-(pyridin-3-ylmethyl)-1H-1,2,4triazol-5-amine and 4-(2,3-dichlorophenyl)-N-(pyridin-3-ylmethyl)4H-1,2,4-triazol-3-amine P2X7 antagonists. Bioorg Med Chem Lett. 2008;18(6):2089-2092.

146. McGaraughty S, Chu KL, Namovic MT, et al. P2X7-related modulation of pathological nociception in rats. Neuroscience. 2007;146(4): 1817-1828.

147. Honore P, Donnelly-Roberts D, Namovic M, et al. The antihyperalgesic activity of a selective P2X7 receptor antagonist, A-839977, is lost in IL-1alphabeta knockout mice. Behav Brain Res. 2009;204(1):77-81.

148. Perez-Medrano A, Donnelly-Roberts DL, Honore P, et al. Discovery and biological evaluation of novel cyanoguanidine P2X(7) antagonists with analgesic activity in a rat model of neuropathic pain. J Med Chem. 2009;52(10):3366-3376.

149. Morytko MJ, Betschmann P, Woller K, et al. Synthesis and in vitro activity of $\mathrm{N}^{\prime}$-cyano-4-(2-phenylacetyl)-N-o-tolylpiperazine1-carboximidamide P2X7 antagonists. Bioorg Med Chem Lett. 2008;18(6):2093-2096.

150. Honore P, Donnelly-Roberts D, Namovic MT, et al. A-740003 [N-(1-\{[(cyanoimino)(5-quinolinylamino) methyl]amino $\}-2$, 2-dimethylpropyl)-2-(3,4-dimethoxyphenyl)acetamide], a novel and selective P2X7 receptor antagonist, dose-dependently reduces neuropathic pain in the rat. J Pharmacol Exp Ther. 2006; 319(3):1376-1385.

151. Donnelly-Roberts DL, Namovic MT, Surber B, et al. [3H]A-804598 ([3H]2-cyano-1-[(1S)-1-phenylethyl]-3-quinolin-5-ylguanidine) is a novel, potent, and selective antagonist radioligand for $\mathrm{P} 2 \mathrm{X} 7$ receptors. Neuropharmacology. 2009;56(1):223-229.

152. Alcaraz L, Baxter A, Bent J, et al. Novel P2X7 receptor antagonists. Bioorg Med Chem Lett. 2003;13(22):4043-4046.

153. Stokes L, Jiang LH, Alcaraz L, et al. Characterization of a selective and potent antagonist of human P2X(7) receptors, AZ11645373. Br J Pharmacol. 2006;149(7):880-887.

154. Baxter A, Bent J, Bowers K, et al. Hit-to-Lead studies: the discovery of potent adamantane amide P2X7 receptor antagonists. Bioorg Med Chem Lett. 2003;13(22):4047-4050.

155. Furber M, Alcaraz L, Bent JE, et al. Discovery of potent and selective adamantane-based small-molecule $\mathrm{P} 2 \mathrm{X}(7)$ receptor antagonists/ interleukin-1beta inhibitors. J Med Chem. 2007;50(24):5882-5885.

156. Michel AD, Chambers LJ, Walter DS. Negative and positive allosteric modulators of the $\mathrm{P} 2 \mathrm{X}(7)$ receptor. $\mathrm{Br} J$ Pharmacol. 2008;153(4):737-750.

157. Duplantier AJ, Dombroski MA, Subramanyam C, et al. Optimization of the physicochemical and pharmacokinetic attributes in a 6-azauracil series of $\mathrm{P} 2 \mathrm{X} 7$ receptor antagonists leading to the discovery of the clinical candidate CE-224,535. Bioorg Med Chem Lett. 2011;21(12):3708-3711.

158. Gum RJ, Wakefield B, Jarvis MF. P2X receptor antagonists for pain management: examination of binding and physicochemical properties. Purinergic Signal. 2012;8(Suppl 1):41-56.

159. McGaraughty S, Wismer CT, Zhu CZ, et al. Effects of A-317491, a novel and selective $\mathrm{P} 2 \mathrm{X} 3 / \mathrm{P} 2 \mathrm{X} 2 / 3$ receptor antagonist, on neuropathic, inflammatory and chemogenic nociception following intrathecal and intraplantar administration. Br J Pharmacol. 2003;140(8):1381-1388.

160. Gever JR, Soto R, Henningsen RA, et al. AF-353, a novel, potent and orally bioavailable $\mathrm{P} 2 \mathrm{X} 3 / \mathrm{P} 2 \mathrm{X} 2 / 3$ receptor antagonist. Br J Pharmacol. 2010;160(6):1387-1398.
161. Weigand LA, Ford AP, Undem BJ. Role for ATP in bronchoconstrictioninduced activation of guinea pig vagal intrapulmonary C-fibers. J Physiol. 2012;S90(Pt16):4109-4120.

162. Kaan TK, Yip PK, Grist J, et al. Endogenous purinergic control of bladder activity via presynaptic $\mathrm{P} 2 \mathrm{X} 3$ and $\mathrm{P} 2 \mathrm{X} 2 / 3$ receptors in the spinal cord. J Neurosci. 2010;30(12):4503-4507.

163. Clark AK, Staniland AA, Marchand F, Kaan TK, McMahon SB, Malcangio M. P2X7-dependent release of interleukin-1beta and nociception in the spinal cord following lipopolysaccharide. J Neurosci. 2010;30(2):573-582.

164. Peng W, Cotrina ML, Han X, et al. Systemic administration of an antagonist of the ATP-sensitive receptor P2X7 improves recovery after spinal cord injury. Proc Natl Acad Sci U S A. 2009;106(30): 12489-12493.

165. Guile SD, Alcaraz L, Birkinshaw TN, et al. Antagonists of the P2X(7) receptor. From lead identification to drug development. J Med Chem. 2009;52(10):3123-3141.

166. Keystone EC, Wang MM, Layton M, Hollis S, McInnes IB. Clinical evaluation of the efficacy of the $\mathrm{P} 2 \mathrm{X} 7$ purinergic receptor antagonist AZD9056 on the signs and symptoms of rheumatoid arthritis in patients with active disease despite treatment with methotrexate or sulphasalazine. Ann Rheum Dis. 2011. [Epub ahead of print].

167. Stock TC, Bloom BJ, Wei N, et al. Efficacy and safety of CE-224,535, an antagonist of $\mathrm{P} 2 \mathrm{X} 7$ receptor, in treatment of patients with rheumatoid arthritis inadequately controlled by methotrexate. J Rheumatol. 2012;39(4):720-727.

168. Marcillo A, Frydel B, Bramlett HM, Dietrich WD. A reassessment of $\mathrm{P} 2 \mathrm{X} 7$ receptor inhibition as a neuroprotective strategy in rat models of contusion injury. Exp Neurol. 2012;233(2):687-692.

169. Inscho EW, Cook AK, Imig JD, Vial C, Evans RJ. Physiological role for $\mathrm{P} 2 \mathrm{X} 1$ receptors in renal microvascular autoregulatory behavior. J Clin Invest. 2003;112(12):1895-1905.

170. Hechler B, Lenain N, Marchese P, et al. A role of the fast ATP-gated $\mathrm{P} 2 \mathrm{X} 1$ cation channel in thrombosis of small arteries in vivo. $J$ Exp Med. 2003;198(4):661-667.

171. Lecut C, Frederix K, Johnson DM, et al. P2X1 ion channels promote neutrophil chemotaxis through Rho kinase activation. J Immunol. 2009; 183(4):2801-2809.

172. Ren J, Bian X, DeVries M, et al. P2X2 subunits contribute to fast synaptic excitation in myenteric neurons of the mouse small intestine. J Physiol. 2003;552(Pt 3):809-821.

173. Ryten M, Koshi R, Knight GE, et al. Abnormalities in neuromuscular junction structure and skeletal muscle function in mice lacking the P2X2 nucleotide receptor. Neuroscience. 2007;148(3): 700-711.

174. Huang YA, Stone LM, Pereira E, et al. Knocking out P2X receptors reduces transmitter secretion in taste buds. J Neurosci. 2011;31(38):13654-13661.

175. Custer EE, KnottTK, CuadraAE, Ortiz-Miranda S, Lemos JR. P2X purinergic receptor knockout mice reveal endogenous ATP modulation of both vasopressin and oxytocin release from the intact neurohypophysis. J Neuroendocrinol. 2012;24(4):674-680.

176. Navarro B, Miki K, Clapham DE. ATP-activated P2X2 current in mouse spermatozoa. Proc Natl Acad Sci U S A. 2011;108(34): 14342-14347.

177. Vlaskovska M, Kasakov L, Rong W, et al. P2X3 knock-out mice reveal a major sensory role for urothelially released ATP. J Neurosci. 2001;21(15):5670-5677.

178. Bian X, Ren J, DeVries M, et al. Peristalsis is impaired in the small intestine of mice lacking the P2X3 subunit. J Physiol. 2003;551(Pt 1): 309-322.

179. Rong W, Gourine AV, Cockayne DA, et al. Pivotal role of nucleotide P2X2 receptor subunit of the ATP-gated ion channel mediating ventilatory responses to hypoxia. J Neurosci. 2003;23(36): 11315-11321.

180. Shimizu I, Iida T, Guan Y, et al. Enhanced thermal avoidance in mice lacking the ATP receptor P2X3. Pain. 2005;116(1-2):96-108. 
181. Wang Y, Mackes J, Chan S, et al. Impaired long-term depression in $\mathrm{P} 2 \mathrm{X} 3$ deficient mice is not associated with a spatial learning deficit. J Neurochem. 2006;99(5):1425-1434.

182. Ke HZ, Qi H, Weidema AF, et al. Deletion of the P2X7 nucleotide receptor reveals its regulatory roles in bone formation and resorption. Mol Endocrinol. 2003;17(7):1356-1367.

183. Li J, Liu D, Ke HZ, Duncan RL, Turner CH. The P2X7 nucleotide receptor mediates skeletal mechanotransduction. $J$ Biol Chem. 2005;280(52):42952-42959.

184. Korcok J, Raimundo LN, Ke HZ, Sims SM, Dixon SJ. Extracellular nucleotides act through $\mathrm{P} 2 \mathrm{X} 7$ receptors to activate NF-kappaB in osteoclasts. J Bone Miner Res. 2004;19(4):642-651.

185. Panupinthu N, Zhao L, Possmayer F, Ke HZ, Sims SM, Dixon SJ. P2X7 nucleotide receptors mediate blebbing in osteoblasts through a pathway involving lysophosphatidic acid. $J$ Biol Chem. 2007;282(5):3403-3412.

186. Kawamura H, Aswad F, Minagawa M, et al. P2X7 receptor-dependent and -independent $\mathrm{T}$ cell death is induced by nicotinamide adenine dinucleotide. J Immunol. 2005;174(4):1971-1979.

187. Suadicani SO, Brosnan CF, Scemes E. P2X7 receptors mediate ATP release and amplification of astrocytic intercellular $\mathrm{Ca} 2+$ signaling. J Neurosci. 2006;26(5):1378-1385.

188. Kawamura H, Aswad F, Minagawa M, Govindarajan S, Dennert G. P2X7 receptors regulate NKT cells in autoimmune hepatitis. J Immunol. 2006;176(4):2152-2160.

189. Nakamoto T, Brown DA, Catalan MA, Gonzalez-Begne M, Romanenko VG, Melvin JE. Purinergic P2X7 receptors mediate ATP-induced saliva secretion by the mouse submandibular gland. J Biol Chem. 2009;284(8):4815-4822.

190. Novak I, Jans IM, Wohlfahrt L. Effect of P2X(7) receptor knockout on exocrine secretion of pancreas, salivary glands and lacrimal glands. J Physiol. 2010;588(Pt 18):3615-3627.

191. Inscho EW, Cook AK, Clarke A, Zhang S, Guan Z. P2X1 receptormediated vasoconstriction of afferent arterioles in angiotensin IIinfused hypertensive rats fed a high-salt diet. Hypertension. 2011; 57(4):780-787.

192. Ito K, Iwami A, Katsura H, Ikeda M. Therapeutic effects of the putative P2X3/P2X2/3 antagonist A-317491 on cyclophosphamideinduced cystitis in rats. Naunyn Schmiedebergs Arch Pharmacol. 2008;377(4-6):483-490.

193. Fairbairn IP, Stober CB, Kumararatne DS, Lammas DA. ATPmediated killing of intracellular mycobacteria by macrophages is a P2X(7)-dependent process inducing bacterial death by phagosomelysosome fusion. J Immunol. 2001;167(6):3300-3307.

194. Shemon AN, Sluyter R, Fernando SL, et al. A Thr357 to Ser polymorphism in homozygous and compound heterozygous subjects causes absent or reduced P2X7 function and impairs ATP-induced mycobacterial killing by macrophages. J Biol Chem. 2006;281(4): 2079-2086.

195. Fernando SL, Saunders BM, Sluyter R, et al. A polymorphism in the P2X7 gene increases susceptibility to extrapulmonary tuberculosis. Am J Respir Crit Care Med. 2007;175(4):360-366.

196. Goncalves RG, Gabrich L, Rosario A Jr, et al. The role of purinergic P2X7 receptors in the inflammation and fibrosis of unilateral ureteral obstruction in mice. Kidney Int. 2006;70(9):1599-1606.

197. Diaz-Hernandez M, Diez-Zaera M, Sanchez-Nogueiro J, et al. Altered P2X7-receptor level and function in mouse models of Huntington's disease and therapeutic efficacy of antagonist administration. FASEB J. 2009;23(6):1893-1906.

198. Parvathenani LK, Tertyshnikova S, Greco CR, Roberts SB, Robertson B, Posmantur R. P2X7 mediates superoxide production in primary microglia and is up-regulated in a transgenic mouse model of Alzheimer's disease. J Biol Chem. 2003;278(15):13309-13317.

199. McLarnon JG, Ryu JK, Walker DG, Choi HB. Upregulated expression of purinergic $\mathrm{P} 2 \mathrm{X}(7)$ receptor in Alzheimer disease and amyloid-beta peptide-treated microglia and in peptide-injected rat hippocampus. J Neuropathol Exp Neurol. 2006;65(11):1090-1097.
200. Skaper SD, Facci L, Culbert AA, et al. P2X(7) receptors on microglial cells mediate injury to cortical neurons in vitro. Glia. 2006;54(3): 234-242.

201. Sanz JM, Chiozzi P, Ferrari D, et al. Activation of microglia by amyloid \{beta\} requires $\mathrm{P} 2 \mathrm{X} 7$ receptor expression. J Immunol. 2009;182(7):4378-4385.

202. Lee HG, Won SM, Gwag BJ, Lee YB. Microglial P2X(7) receptor expression is accompanied by neuronal damage in the cerebral cortex of the APPswe/PS1dE9 mouse model of Alzheimer's disease. Exp Mol Med. 2011;43(1):7-14.

203. Taylor SR, Turner CM, Elliott JI, et al. P2X7 deficiency attenuates renal injury in experimental glomerulonephritis. $J \mathrm{Am}$ Soc Nephrol. 2009;20(6):1275-1281.

204. Wilhelm K, Ganesan J, Muller T, et al. Graft-versus-host disease is enhanced by extracellular ATP activating P2X7R. Nat Med. 2010;16(12):1434-1438

205. Zhou D, Chen ML, Zhang YQ, Zhao ZQ. Involvement of spinal microglial $\mathrm{P} 2 \mathrm{X} 7$ receptor in generation of tolerance to morphine analgesia in rats. J Neurosci. 2010;30(23):8042-8047.

206. Gandelman M, Peluffo H, Beckman JS, Cassina P, Barbeito L. Extracellular ATP and the P2X7 receptor in astrocyte-mediated motor neuron death: implications for amyotrophic lateral sclerosis. J Neuroinflammation. 2010;7:33.

207. Kim JE, Kang TC. The P2X7 receptor-pannexin-1 complex decreases muscarinic acetylcholine receptor-mediated seizure susceptibility in mice. J Clin Invest. 2011;121(5):2037-2047.

208. Keating C, Pelegrin P, Martinez CM, Grundy D. P2X7 receptor-dependent intestinal afferent hypersensitivity in a mouse model of postinfectious irritable bowel syndrome. J Immunol. 2011;187(3): $1467-1474$.

209. Martins JP, Silva RB, Coutinho-Silva R, et al. The role of P2X7 purinergic receptors in inflammatory and nociceptive changes accompanying cyclophosphamide-induced haemorrhagic cystitis in mice. Br J Pharmacol. 2012;165(1):183-196.

210. Barden N, Harvey M, Gagne B, et al. Analysis of single nucleotide polymorphisms in genes in the chromosome 12Q24.31 region points to P2RX7 as a susceptibility gene to bipolar affective disorder. Am J Med Genet B Neuropsychiatr Genet. 2006;141B(4): 374-382.

211. Lucae S, Salyakina D, Barden N, et al. P2RX7, a gene coding for a purinergic ligand-gated ion channel, is associated with major depressive disorder. Hum Mol Genet. 2006;15(16):2438-2445.

212. Hejjas K, Szekely A, Domotor E, et al. Association between depression and the Gln460 Arg polymorphism of P2RX7 gene: a dimensional approach. Am J Med Genet B Neuropsychiatr Genet. 2009;150B(2):295-299.

213. McQuillin A, Bass NJ, Choudhury K, et al. Case-control studies show that a non-conservative amino-acid change from a glutamine to arginine in the P2RX7 purinergic receptor protein is associated with both bipolar- and unipolar-affective disorders. Mol Psychiatry. 2009;14(6):614-620.

214. Gidlof O, Smith JG, Melander O, et al. A common missense variant in the ATP receptor $\mathrm{P} 2 \mathrm{X} 7$ is associated with reduced risk of cardiovascular events. PLoS One. 2012;7(5):e37491.

215. Evans RJ, Lewis C, Buell G, Valera S, North RA, Surprenant A. Pharmacological characterization of heterologously expressed ATP-gated cation channels (P2x purinoceptors). Mol Pharmacol. 1995;48(2):178-183.

216. Ullmann H, Meis S, Hongwiset D, et al. Synthesis and structure-activity relationships of suramin-derived P2Y11 receptor antagonists with nanomolar potency. $J$ Med Chem. 2005;48(22): 7040-7048.

217. North RA, Surprenant A. Pharmacology of cloned P2X receptors. Annu Rev Pharmacol Toxicol. 2000;40:563-580.

218. Fonfria E, Clay WC, Levy DS, et al. Cloning and pharmacological characterization of the guinea pig $\mathrm{P} 2 \mathrm{X} 7$ receptor orthologue. $\mathrm{Br} J$ Pharmacol. 2008;153(3):544-556. 
219. Hulsmann M, Nickel P, Kassack M, Schmalzing G, Lambrecht G, Markwardt F. NF449, a novel picomolar potency antagonist at human P2X1 receptors. Eur J Pharmacol. 2003;470(1-2):1-7.

220. Hausmann R, Rettinger J, Gerevich Z, et al. The suramin analog 4,4', $4^{\prime \prime}, 4^{\prime \prime \prime}$-(carbonylbis(imino-5,1,3-benzenetriylbis (carbonylimino))) tetra-kis-benzenesulfonic acid (NF110) potently blocks P2X3 receptors: subtype selectivity is determined by location of sulfonic acid groups. Mol Pharmacol. 2006;69(6):2058-2067.

221. Jung KY, Moon HD, Lee GE, Lim HH, Park CS, Kim YC. Structureactivity relationship studies of spinorphin as a potent and selective human P2X(3) receptor antagonist. J Med Chem. 2007;50(18):4543-4547.

222. Donnelly-Roberts D, McGaraughty S, Shieh CC, Honore P, Jarvis MF. Painful purinergic receptors. J Pharmacol Exp Ther. 2008;324(2):409-415.
223. Roman S, Cusdin FS, Fonfria E, et al. Cloning and pharmacological characterization of the dog $\mathrm{P} 2 \mathrm{X} 7$ receptor. Br J Pharmacol. 2009;158(6):1513-1526.

224. Bradley HJ, Browne LE, Yang W, Jiang LH. Pharmacological properties of the rhesus macaque monkey $\mathrm{P} 2 \mathrm{X} 7$ receptor. $\mathrm{Br} J$ Pharmacol. 2011;164(2b):743-754.

225. Michel AD, Chambers LJ, Clay WC, Condreay JP, Walter DS, Chessell IP. Direct labelling of the human $\mathrm{P} 2 \mathrm{X} 7$ receptor and identification of positive and negative cooperativity of binding. Br J Pharmacol. 2007;151(1):103-114.

\section{Publish your work in this journal}

Cell Health and Cytoskeleton is an international, peer-reviewed open access journal focusing on all aspects of cell structure and function contributing to normal physiology and cell health and exploring the pathogenesis of cell dysfunction leading to adverse conditions and disease in the organism. The journal welcomes papers covering original research,

\section{Dovepress}

basic science, reviews and evaluations, guidelines, expert opinion and commentary, case reports and extended reports. The manuscript management system is completely online and includes a very quick and fair peerreview system, which is all easy to use. Visit http://www.dovepress.com/ testimonials.php to read real quotes from published authors.

Submit your manuscript here: http://www.dovepress.com/cell-health-and-cytoskeleton-journal 